\title{
AFTERSHOCK DISTRIBUTION OF THE 1982 URAKAWA-OKI EARTHQUAKE DETERMINED BY OCEAN BOTTOM SEISMOGRAPHIC AND LAND OBSERVATIONS
}

\author{
Takaya Iwasaki, ${ }^{*}$ Naoshi Hirata, ${ }^{* *}$ Kiyoshi Suyehiro, ${ }^{* * *}$ \\ Toshihiko Kanazawa, ${ }^{* *}$ Taku URABE, ${ }^{* *}$, 1) Takeo MoRIYA,**** \\ and Hideki SHIMAMURA* \\ * Laboratory for Ocean Bottom Seismology, Faculty \\ of Science, Hokkaido University, Sapporo, Japan \\ ** Geophysical Institute, Faculty of Science, \\ the University of Tokyo, Tokyo, Japan \\ *** Observation Center for Earthquake Prediction, \\ Faculty of Science, Tohoku University, Sendai, Japan \\ **** Department of Geophysics, Faculty of Science, \\ Hokkaido University, Sapporo, Japan \\ (Received October 17, 1983; Revised January 31, 1984)
}

The Urakawa-Oki earthquake $(M=7.1)$ occurred offshore of Urakawa, Hokkaido, Japan, on March 21, 1982. In order to investigate the aftershock activity of this event, we deployed four ocean bottom seismographs (OBS's) off Urakawa. During an observation period from March 29 to April 6, the OBS network detected more than 4,500 earthquakes. Magnitude range of these events is from -2.0 to 5.0 .

Aftershock distribution of the Urakawa-Oki earthquake was determined on the basis of the OBS and land observations. In the analysis, we selected about 250 aftershocks with $M \geq 2.0$, because the seismic signals from these events were recorded clearly both by the OBS's and the land stations around the aftershock area. Hypocenter determination was carried out using a method of inversion analysis. Most of the aftershocks were located in a region of $42^{\circ} 00^{\prime}-42^{\circ} 20^{\prime} \mathrm{N}$ and $142^{\circ} 25^{\prime}-142^{\circ} 40^{\prime} \mathrm{E}$. These events were distributed in a depth range of $10-30 \mathrm{~km}$. The characteristic dimensions of the aftershock area were estimated as $35 \mathrm{~km} \times 25 \mathrm{~km}$. The events in the southern part (south of $42^{\circ} 15^{\prime} \mathrm{N}$ ) were distributed on a plane with an area of $20-25 \mathrm{~km} \times 10-15 \mathrm{~km}$ dipping $20-30^{\circ}$ northward. In the northern part of the aftershock area, we found another trend of aftershocks which inclined southward with a high angle of $60-70^{\circ}$. The events in this group were located on a plane with a relatively narrow area of $10 \mathrm{~km} \times 10-15 \mathrm{~km}$. The aftershock distribution obtained in the present analysis suggests that the fracture mechanism of the Urakawa-Oki earthquake was very complicated.

1) Present address: Department of Physics, Faculty of Science, Kyushu University, Fukuoka, Japan. 


\section{Introduction}

The Urakawa-Oki earthquake of March 21, $1982(M=7.1)$ took place offshore of Urakawa, Hokkaido, Japan (Fig. 1). The epicenter, focal depth, and origin time of this event were determined by the Research Center for Earthquake Predic-

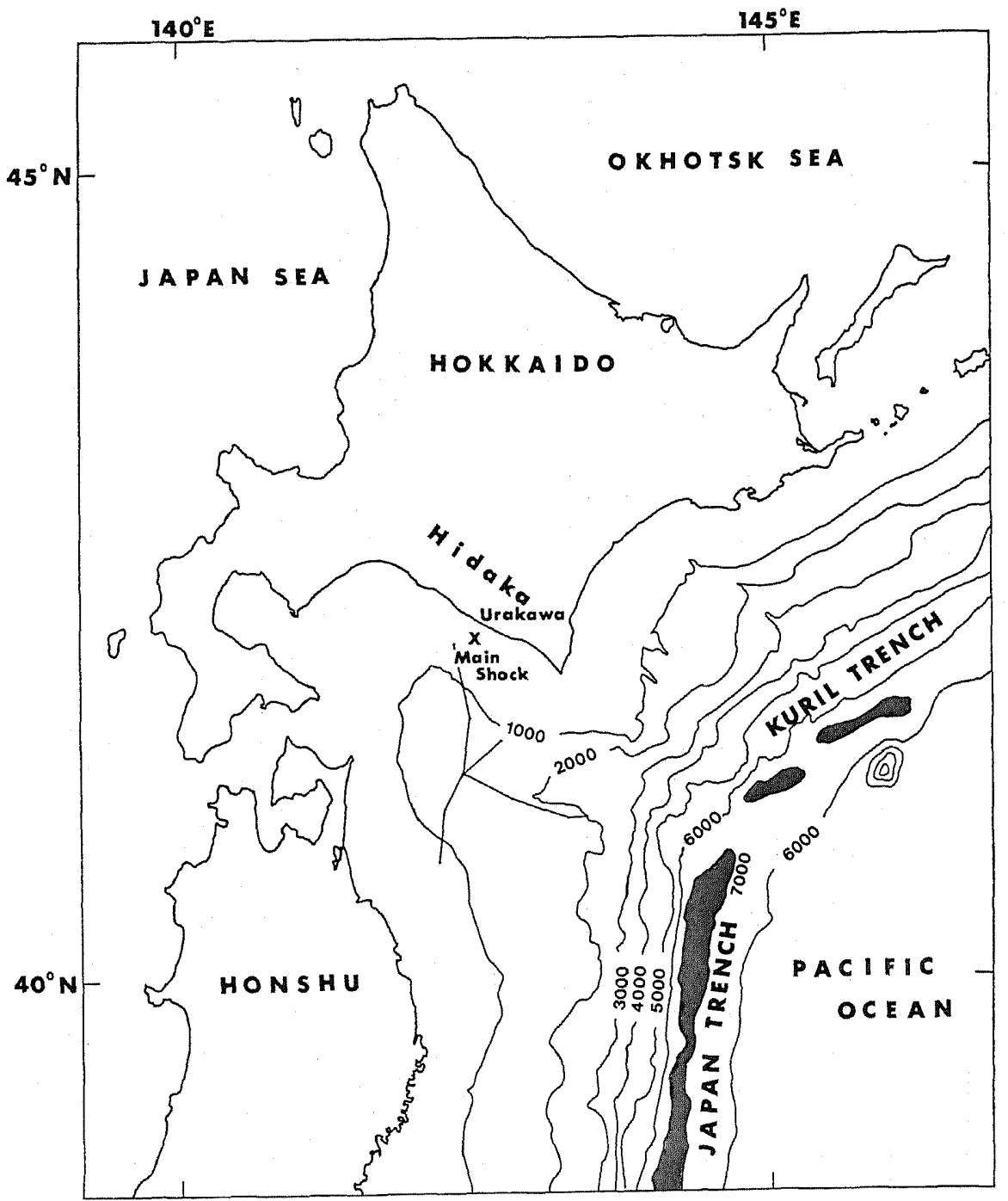

Fig. 1. Map of northern Japan. Isobaths are in meters. The shaded region corresponds to the area where the water depth exceeds $7,000 \mathrm{~m}$. The epicenter of the Urakawa-Oki earthquake (SuzuKI and MotoyA, 1983) is shown by a cross. The solid lines denote locations of seismic refraction and reflection measurements by AsANo et al. (1979). 


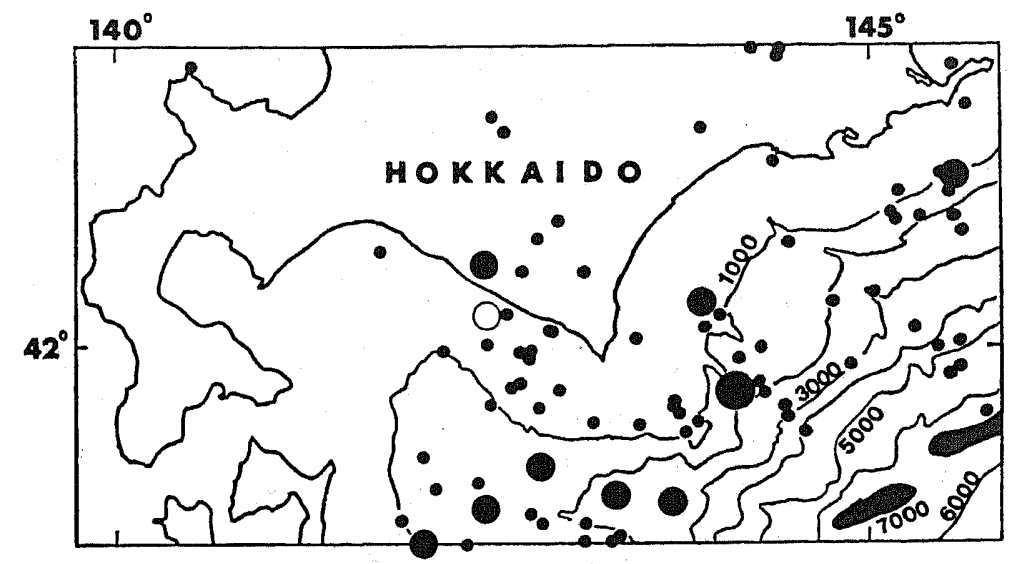

Fig. 2. Epicenter map of earthquakes with $M \geq 6.0$ occurring in and off southern Hokkaido from 1931 through 1980. The hypocentral parameters of these events were compiled by UTSU (1982). The small, medium, and large circles correspond to events with $6.0 \leq M<7.0,7.0 \leq M<7.8$, and $M \geq 7.8$, respectively. The epicenter of the 1982 Urakawa-Oki earthquake is shown by an open circle.

tion (RCEP) of Hokkaido University (SUzUKI and MotoYA, 1983):

Epicenter, $42^{\circ} 10^{\prime} \mathrm{N}, 142^{\circ} 32^{\prime} \mathrm{E}$;

Focal depth, $27 \mathrm{~km}$;

Origin time (Japan standard time), $11 \mathrm{hr} 32 \mathrm{~min} 06.00 \mathrm{sec}$.

Figure 2 shows epicenters of earthquakes with $M \geq 6.0$ occurring in and off the southern part of Hokkaido for the past fifty years. Generally, the seismic activity off the Pacific coast of Hokkaido is high due to the subduction of the Pacific plate. In the hypocentral region of the Urakawa-Oki earthquake, the depth to the upper boundary of the Pacific plate is $60-80 \mathrm{~km}$. Hence, the Urakawa-Oki earthquake is considered one of the largest events to occur above the plate boundary.

After the Urakawa-Oki earthquake, a large number of aftershocks were observed at RCEP seismograph stations. According to a preliminary report by RCEP, about two thirds of the aftershocks took place beneath the sea. In order to investigate the time and spatial distributions of the aftershock activity, MORIYA et al. $(1983 \mathrm{a}, \mathrm{b})$ deployed thirteen temporary seismograph stations in the coastal region of Hidaka. Most of these stations, however, were installed only in the northern part of the aftershock area due to geographical limitations. Hence, it seems difficult to determine reliable aftershock locations only by land observation. Eight days after the Urakawa-Oki earthquake, four ocean bottom seismographs (OBS's) of a pop-up type were deployed off Urakawa to cover the southern part of the aftershock area (ShImAmura et al., 1983). During an observation period from March 29 to April 6, the OBS network detected more than 4,500 events. 


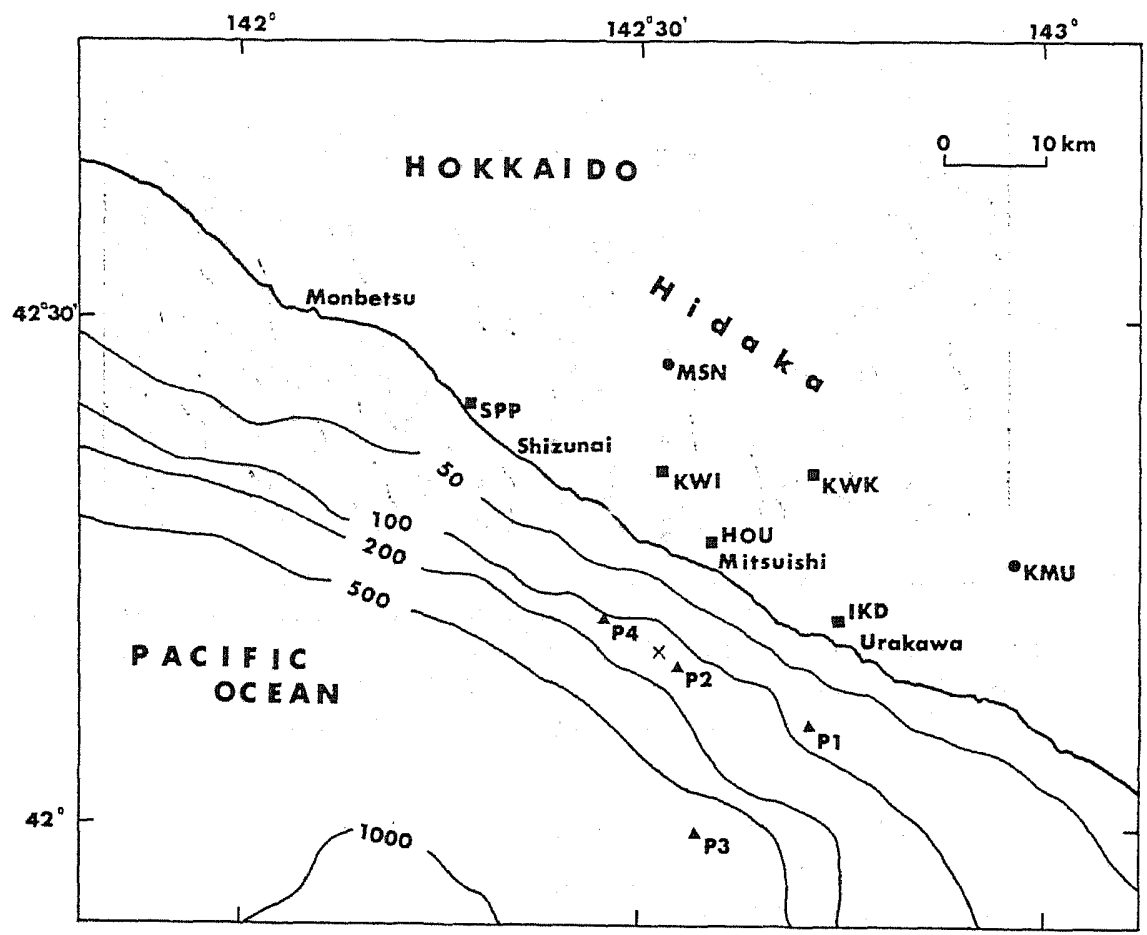

Fig. 3. Location map of seismograph stations. Isobaths are in meters. Closed triangles, circles, and squares denote the OBS stations, permanent land stations of RCEP and temporary land stations deployed by MorIYA et al. (1983a, b), respectively. The epicenter of the Urakawa-Oki earthquake is shown by a cross.

The main purpose of this paper is to make clear the spatial distribution of aftershocks of the 1982 Urakawa-Oki earthquake. In the analysis, we used arrival time data at four OBS's, two permanent land stations of RCEP, and five temporary land stations deployed by MoriYa et al. (1983a, b). These seismograph stations cover the entire aftershock area. Hypocenter determination was based on a new method of inversion analysis presented by MATSU'URA and Hirata (1982).

\section{Aftershock Observation by $O B S^{\prime}$ 's}

The first aftershock observation by OBS's was done seventeen days after the 1978 Miyagi-Oki earthquake, which occurred off the Pacific coast of the Tohoku district (northern Honshu), Japan (YamAda et al., 1978; MATSU'URA et al., 1978; YAMADA, 1980). From the OBS data obtained, YAMADA (1980) clarified the fine structure of the aftershock distribution. This investigation confirmed that OBS observation is useful for a precise study of aftershock activity in the sea area. 
Table 1. Locations of OBS's.

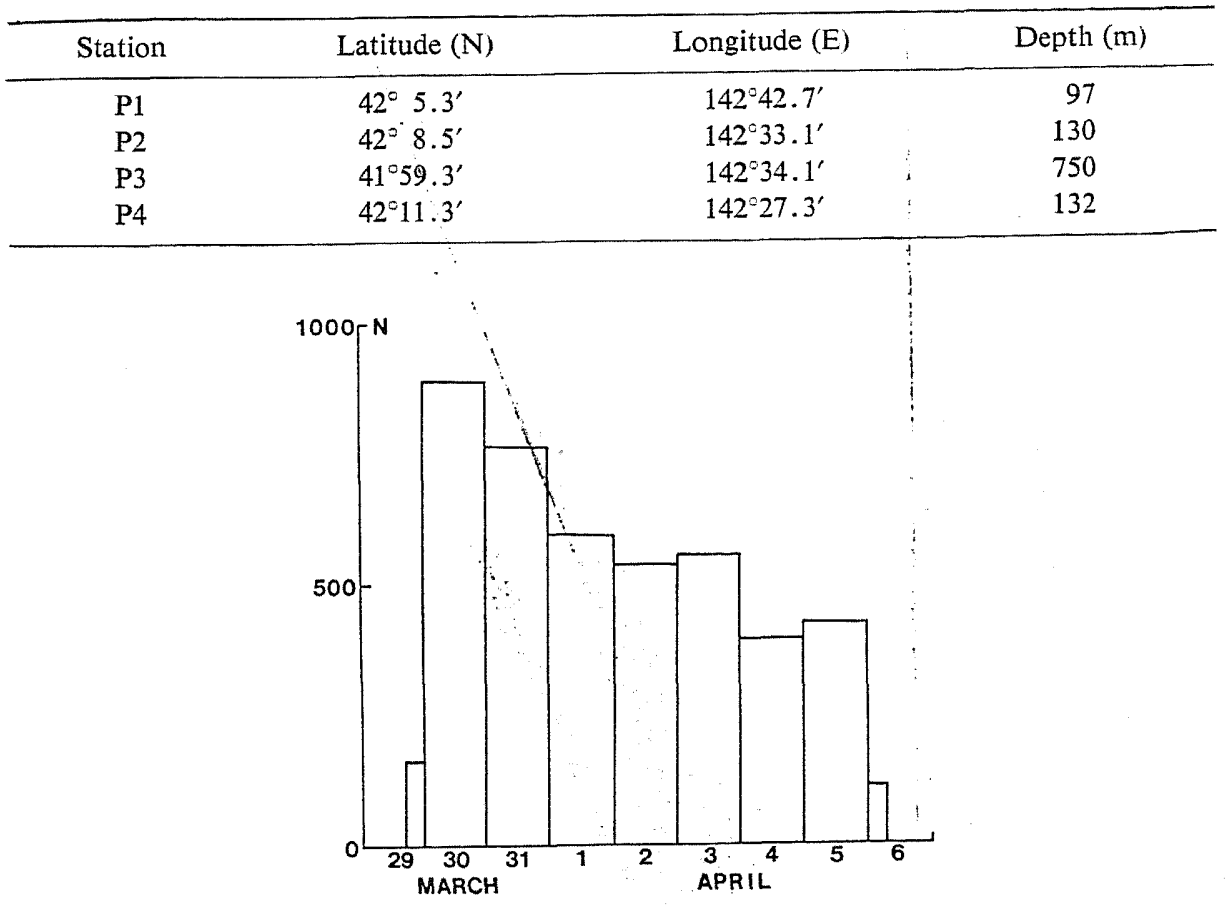

(a)

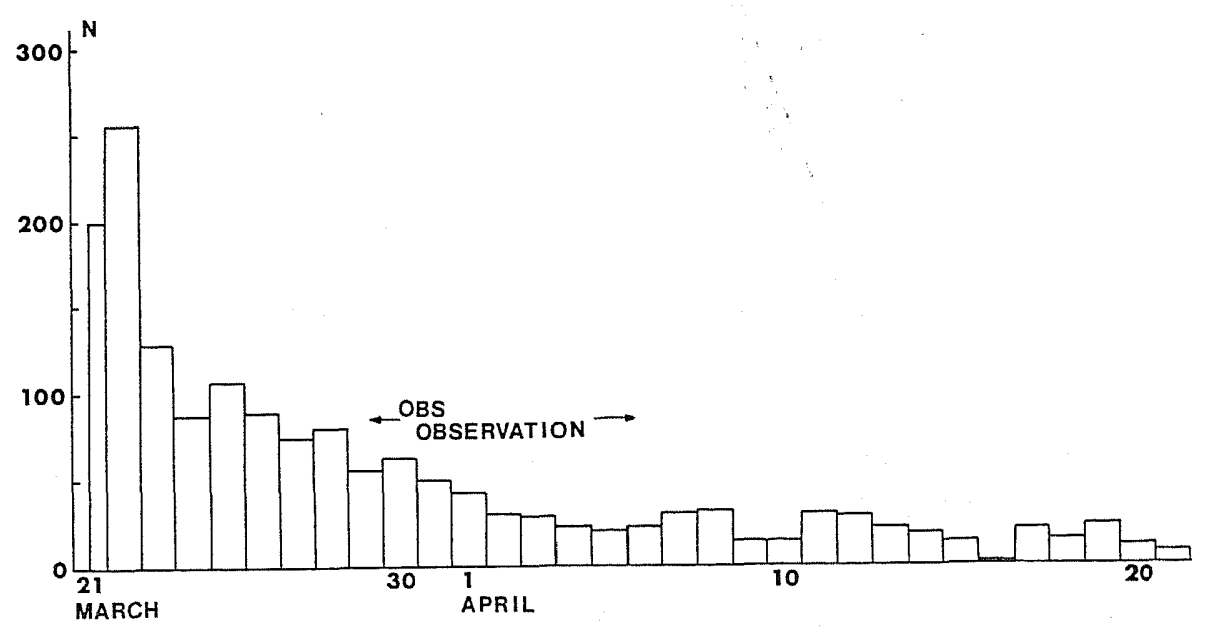

(b)

Fig. 4. Daily frequency of aftershocks. (a) Daily frequency of aftershocks detected at P2. The magnitude of event ranges from -2.0 to 5.0. (b) Daily frequency of aftershocks with $M \geq 2.0$ observed by the land network of RCEP (after MoTOYA (1983)). 


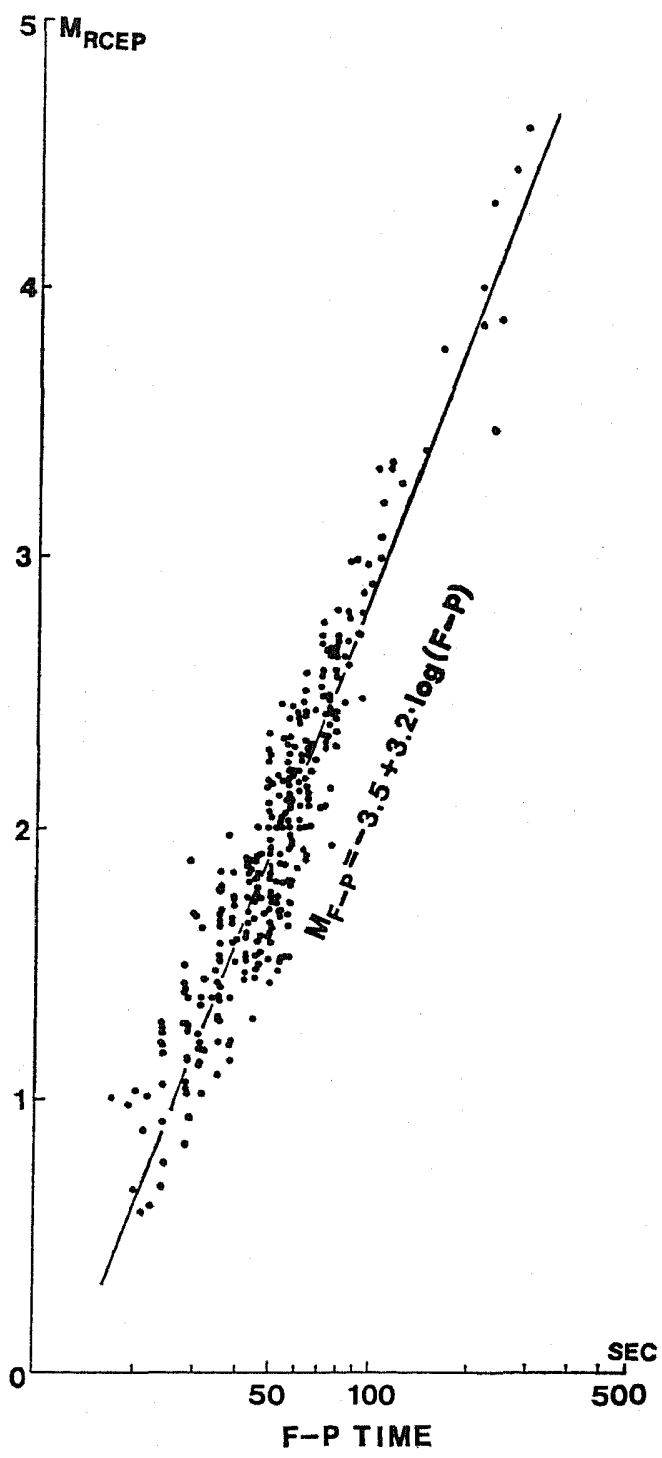

Fig. 5. Relation between magnitude and signal duration time (F-P time) at P2. $M_{\mathrm{RCEP}}$ denotes the magnitude determined by RCEP. By using the least squares method, the empirical relation, $M_{\mathrm{F}-\mathrm{P}}=-3.5+3.2 \log$ (F-P time) was obtained (solid line).

Eight days after the Urakawa-Oki earthquake, four OBS's of a pop-up type were deployed off Urakawa by a 17 ton fishery boat, Hokushin Maru No. 18. The observation sites are shown in Fig. 3 and Table 1. The OBS's P1, P2, and P4, were recovered on April 6 by Training Ship Hokusei Maru, Hokkaido University. The OBS unit deployed at P3 was recovered later because of the trouble of radio transmitter. 


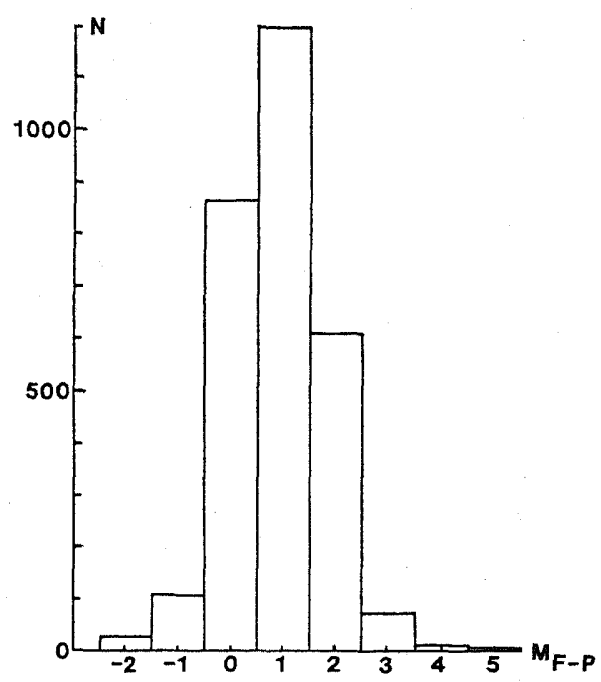

Fig. 6. Histogram of aftershocks detected at P2 with respect to magnitude $\left(M_{F-P}\right)$. The detectability of the OBS is almost uniform for events of $M_{F \rightarrow P} \geq 1.0$.

The OBS system used in the present investigation was designed to be compact and convenient for temporary seismographic observation (ASADA et al., 1979; YAMADA, 1980; YAMADA et al., 1981, 1983).

Each OBS unit is equipped with both vertical and horizontal geophones. The natural frequencies of geophone are $3.0 \mathrm{~Hz}$ for the vertical component and $4.5 \mathrm{~Hz}$ for the horizontal component. Seismic signals from the geophones are recorded continuously on a standard cassette magnetic tape together with a BCD time code. All the instruments (geophones, BCD time code generator, amplifiers, recorder, and batteries) are housed in a spherical glass pressure vessel with a diameter of $43 \mathrm{~cm}$. The recording period of this OBS system is normally eleven days, that can be extended up to twenty-five days.

The OBS network off Urakawa detected more than 4,500 aftershocks. Figure 4(a) shows the daily frequency of aftershocks at P2, which was deployed near the main shock. The OBS detected 400-900 events a day. In Fig. 4(b), the daily frequency obtained by land observation is presented. Aftershock activity was found to have decreased very slowly during the period of the OBS observation. In Fig. 5, signal duration time ( $\mathrm{F}-\mathrm{P}$ time) at $\mathrm{P} 2$ is plotted against magnitude by RCEP, $M_{\mathrm{RCEP}}$. Applying the least squares method, we obtained an empirical relation between $\mathrm{F}-\mathrm{P}$ time and magnitude $\left(M_{\mathrm{F}-\mathrm{P}}\right)$

$$
M_{\mathrm{F}-\mathrm{P}}=-3.5+3.2 \log \text { (F-P time). }
$$

Figure 6 shows the histogram of events with respect to $M_{\mathrm{F}-\mathrm{P}}$. The range of estimated magnitude, $M_{F-P}$, is from -2.0 to 5.0. The number of earthquakes with $M_{\mathrm{F}-\mathrm{P}} \geq 2.0$ is 283 . During the period of OBS observation, the RCEP land network detected 271 earthquakes with $M_{\mathrm{RCEP}} \geq 2.0$ (Suzuki, personal communica- 


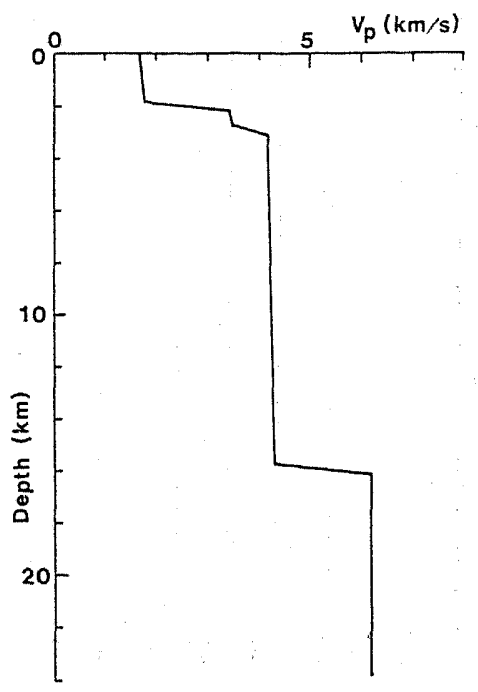

Fig. 7. Velocity structure adopted for the hypocenter determination. The P-wave velocity and thickness of each layer were determined on the basis of the crustal structure off Hidaka presented by Asano et al. (1979).

tion). These results show that the detectabilities of the OBS and land stations are almost uniform for the aftershocks with $M \geq 2.0$. For this reason, we present the hypocenter distribution of these earthquakes in the following two sections.

\section{Aftershock Distribution Determined from OBS Data}

The main purpose of the present paper is to investigate the spatial distribution of aftershocks occurring after the Urakawa-Oki earthquake on the basis of the OBS and land observations. In this analysis, we selected 271 earthquakes with $M_{\mathrm{RCEP}} \geq 2.0$ according to the aftershock list compiled by Suzuki (personal communication).

The crustal structure in the aftershock region of the Urakawa-Oki earthquake is not known precisely enough. Asano et al. (1979) determined the velocity structure off Hidaka from seismic refraction and reflection measurements along the lines shown in Fig. 1, and found a thick sedimentary layer beneath the sea bottom. In the northern part of their profiles, the $\mathrm{P}$-wave velocity and thickness of the sedimentary layer were determined as $4.2 \mathrm{~km} / \mathrm{sec}$ and $10-13 \mathrm{~km}$, respectively. According to FUIII and MoRIYA (1983), such a thick sedimentary layer was found near Shizunai and Urakawa, but not in the vicinity of Mitsuishi (see Fig. 3). Based upon the inversion analysis of seismic data, TAKANAMI (1982) and MIYAMACHI and MoRIYA (1983) showed that there is lateral heterogenity in P-wave velocity beneath the Hidaka district. These investigations suggest that the 


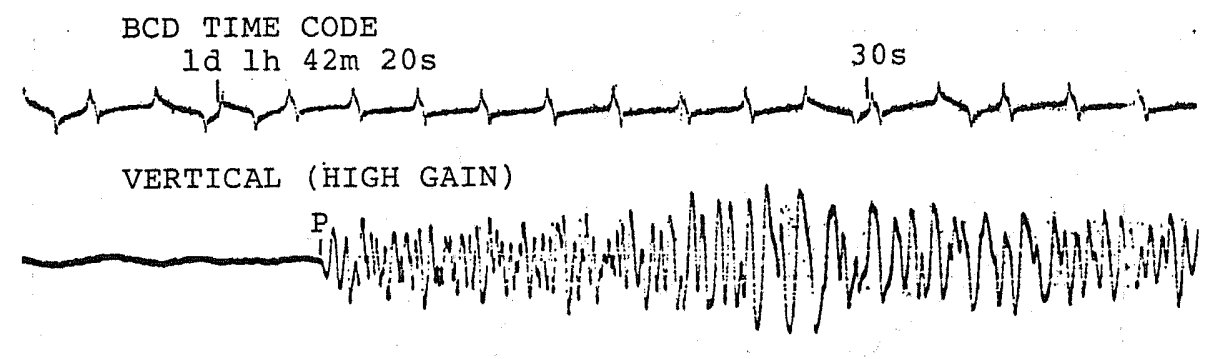

VERTICAL (LOW GAIN)

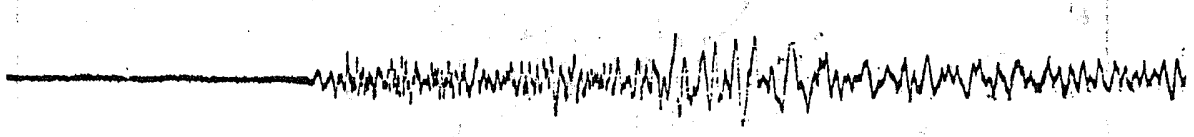

HORIZONTAL

(a)

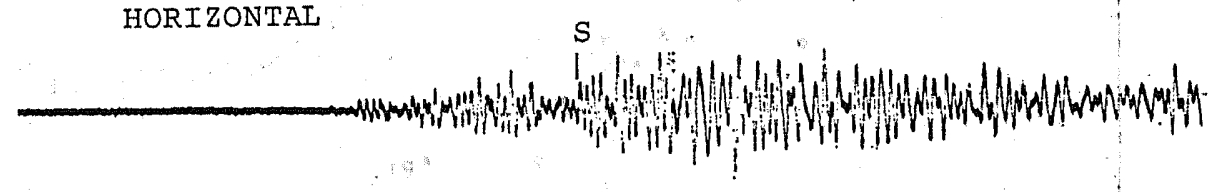

Fig. 8. Example of seismograms recorded at P1. This event occurred on April 1 in the southern edge of the aftershock area. The epicentral distance, focal depth, and magnitude are $7.0 \mathrm{~km}, 18.0 \mathrm{~km}$, and 2.5 , respectively. The symbols $P$ and $S$ denote the arrivals of $P$ and $S$ waves.

crustal structure in the aftershock region of the Urakawa-Oki earthquake also varies laterally.

As a first step of the analysis, we tried to determine the aftershock locations only from the OBS data using the velocity structure off Hidaka (Fig. 7). Figure 8 shows an example of seismograms at the OBS station P1. Most of the seismograms obtained by OBS observation had sharp onset of $\mathbf{P}$ wave. Hence, we could read the arrival time within accuracy of $0.05 \mathrm{sec}$.

\subsection{Method of hypocenter determination}

Earthquake locations are usually determined by solving observation equations of arrival times in the framework of a least squares method. In this approach, however, we are confronted by computational instability when the set of observation equations is reduced to an under-determined system. MATSU'URA and Hirata (1981) pointed out that such a difficulty can be avoided by using a generalized inversion technique.

Recently, MATSU'URA and HIRATA (1982) treated a quasi-linear inverse problem with $a$ priori information about unknown parameters. Using a singular value decomposition technique for rectangular matrices, they obtained a solution which minimizes a total variance of estimation error in the framework of a generalized 


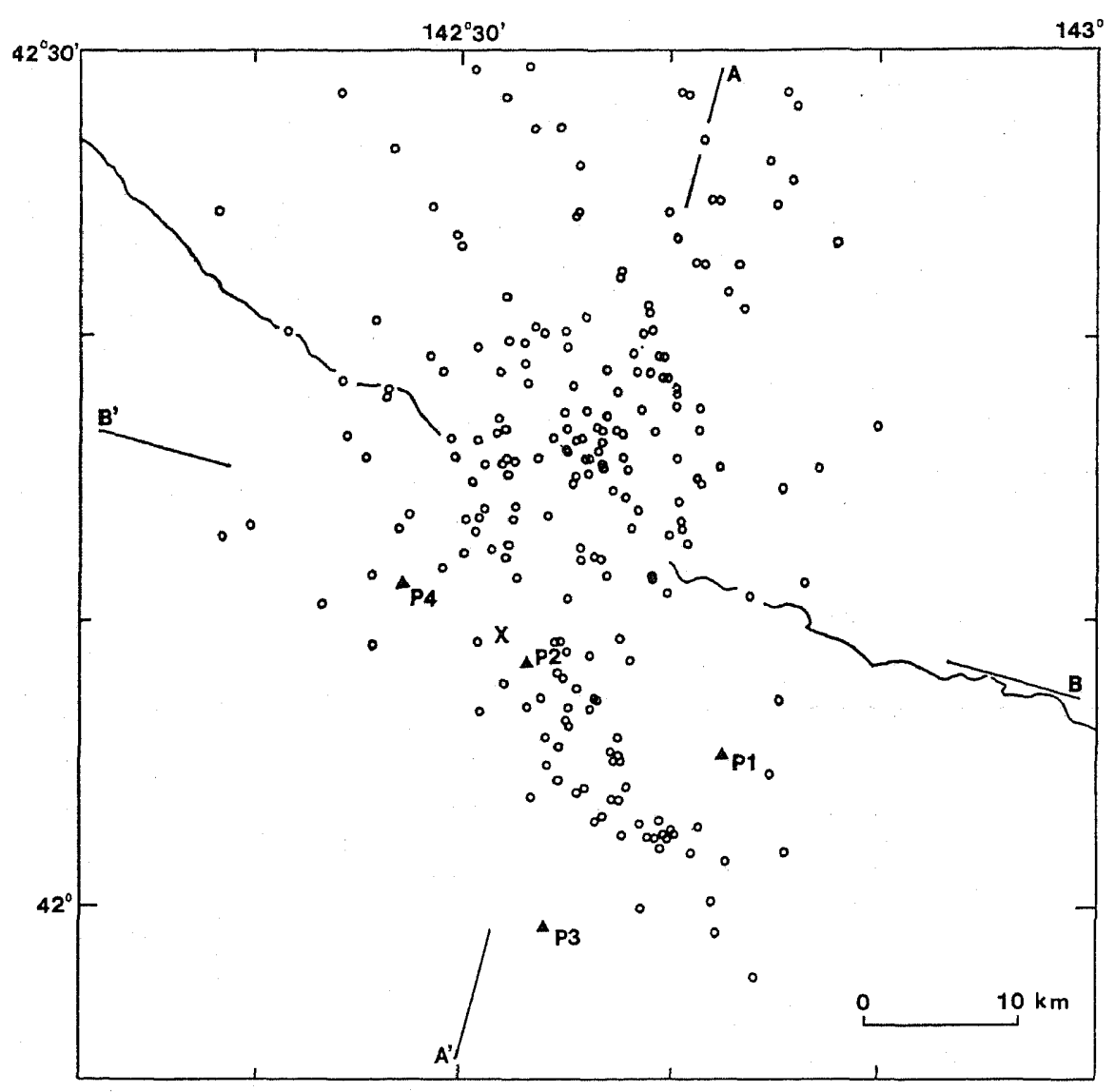

Fig. 9(a)

Fig. 9. Aftershock distribution determined from OBS data. (a) Epicenter map. The OBS stations are shown by solid triangles. A cross denotes the epicenter of the main shock obtained by SuzUKI and MoToYA (1983). (b) Hypocenter distribution in vertical section with strike of $\mathrm{N} 15^{\circ} \mathrm{E}-\mathrm{S} 15^{\circ} \mathrm{W}\left(\mathrm{A}-\mathrm{A}^{\prime}\right)$. (c) Hypocenter distribution in vertical section with strike of $S 75^{\circ} \mathrm{E}-\mathrm{N} 75^{\circ} \mathrm{W}\left(\mathrm{B}-\mathrm{B}^{\prime}\right)$.

least squares approach. In under-determined cases, this solution inherently depends on the initial guess of unknown parameters, and then the uncertainties of the solution are evaluated by the covariances of estimation error which result not only from the random noise in data, but also from the probable error in the initial guess. Hirata et al. (1983), applying this new inverse formalism to the hypocenter determination, investigated spatial distribution of microearthquakes beneath the Japan Trench. Such an approach is particularly useful for a case in which the number of seismograph stations is limited.

Using a similar procedure, we determined aftershock locations from P-wave data at the OBS stations. As the initial guesses of the computation, we used the 


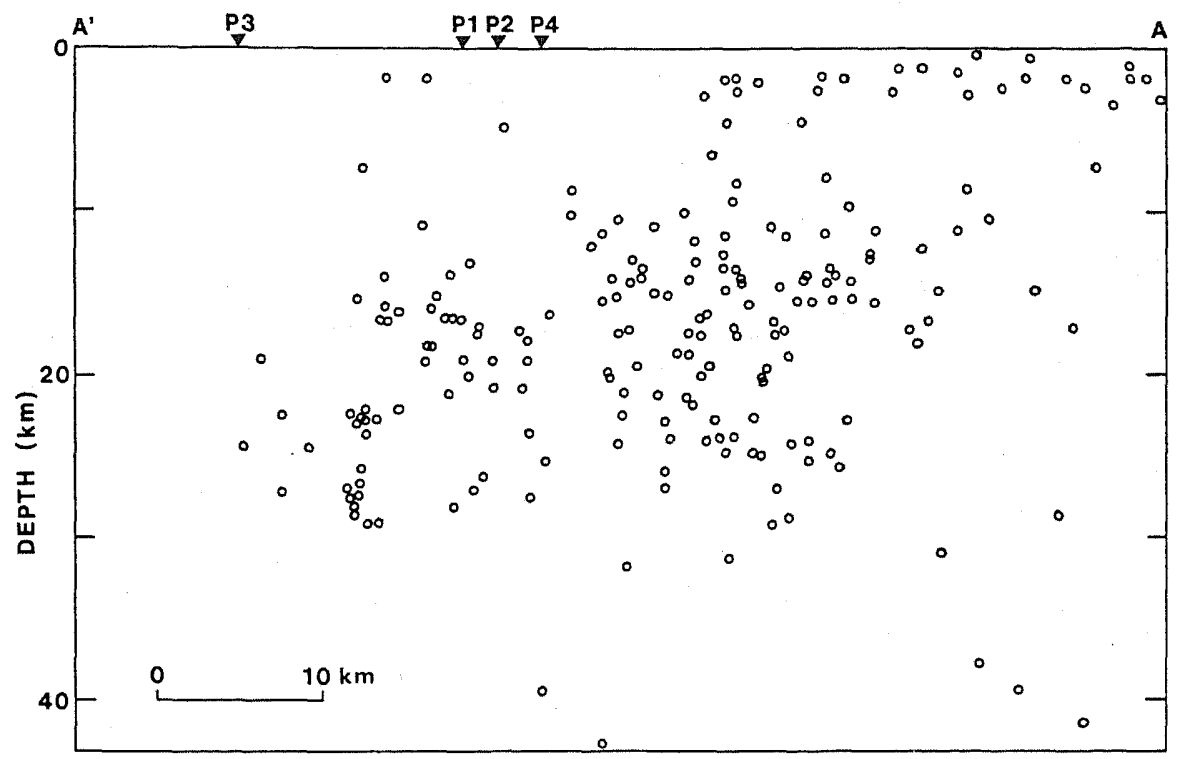

Fig. 9(b)

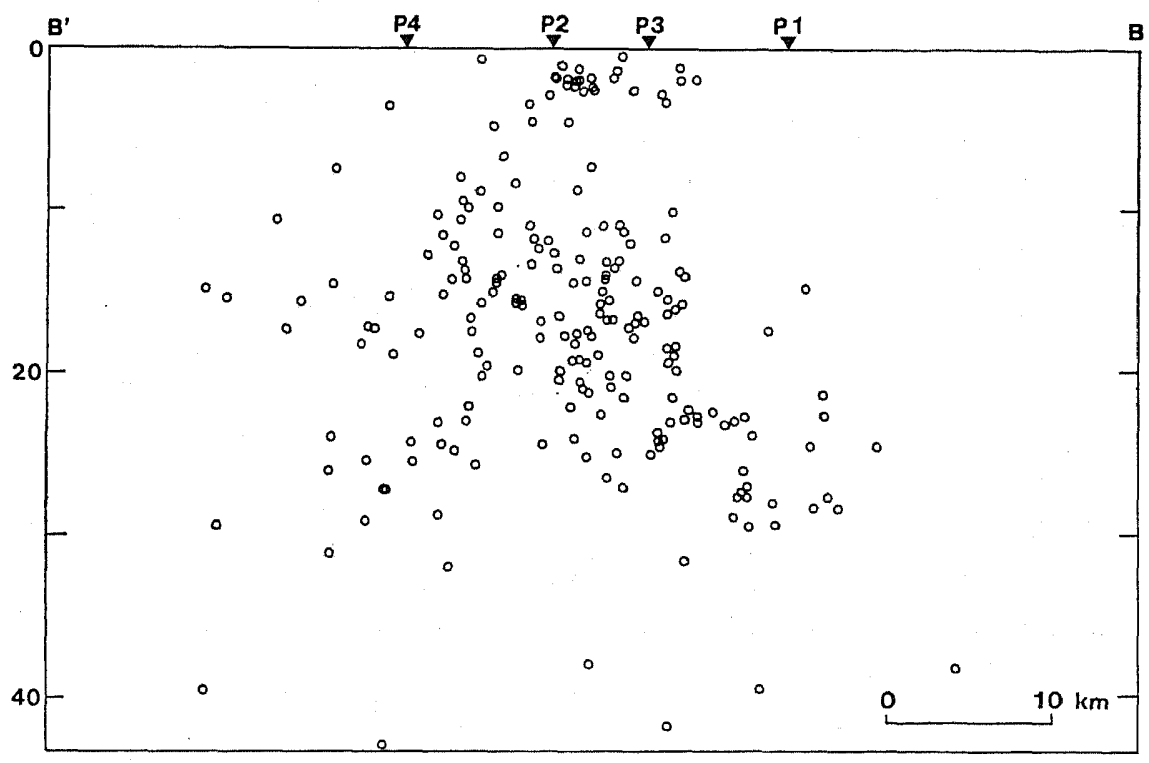

Fig. $9(\mathrm{c})$ 


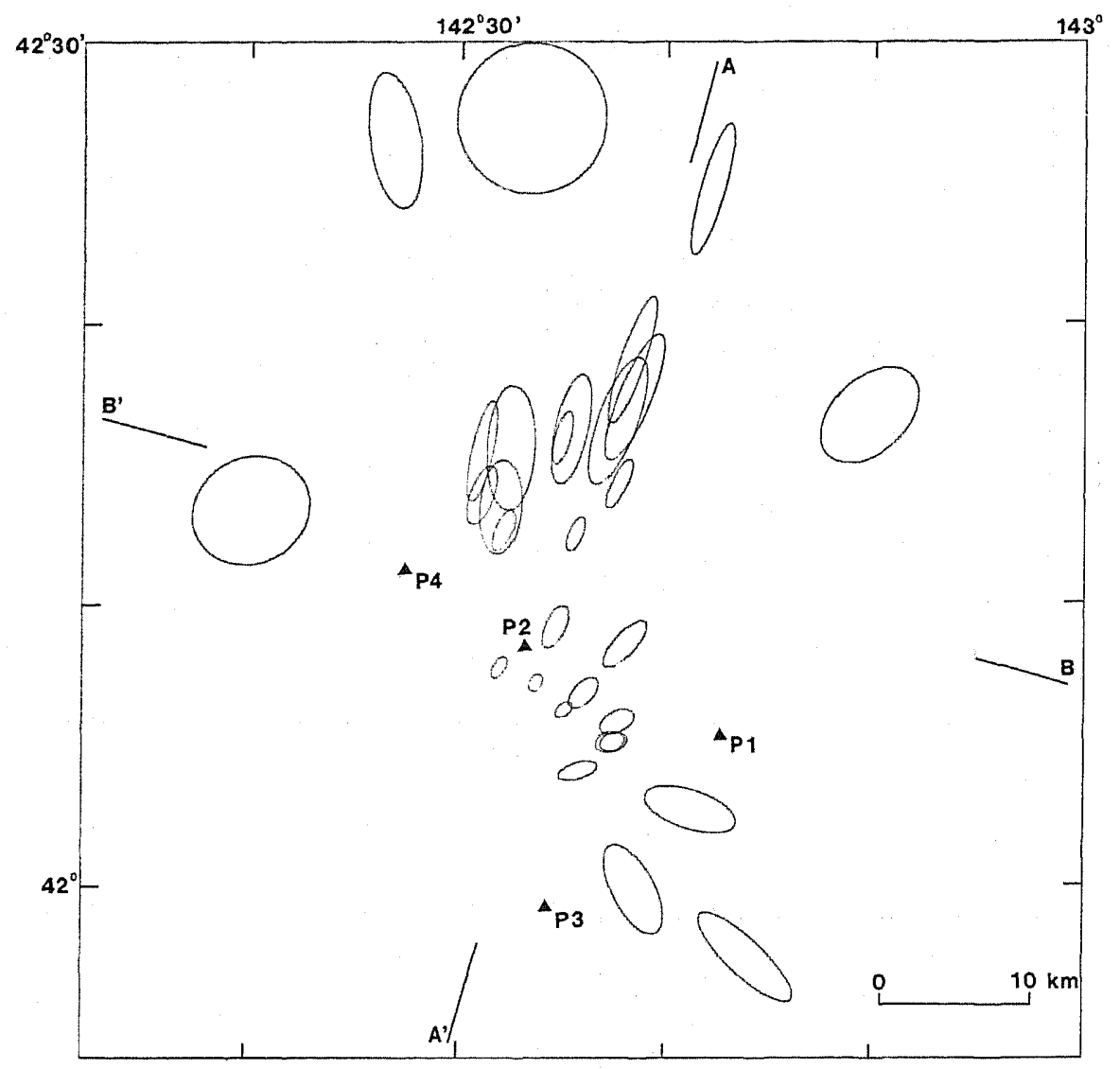

Fig. 10(a)

Fig. 10. Error ellipses of hypocenters determined from OBS data. (a) Horizontal section. (b) Vertical section $\left(A-A^{\prime}\right)$. (c) Vertical section $\left(B-B^{\prime}\right)$.

hypocenters and origin times by the routine observation of RCEP. These parameters, however, are believed to contain systematic errors for the following reasons:

1) The RCEP network covers only the northern part of the aftershock region.

2) In the hypocenter determination, RCEP uses a travel time table presented by ICHIKAWA and Mochizuki (1971). The P-wave velocity assumed in this table is probably too high compared with the actual $\mathrm{P}$-wave velocity in the aftershock region.

Hence, we took the probable errors in the initial guess to be relatively large values, that is, $5 \mathrm{~km}$ for epicenter, $10 \mathrm{~km}$ for focal depth, and $3 \mathrm{sec}$ for origin time. The random noise in arrival time data, which results from reading error and inadequate modeling of the velocity structure, was assumed to be $0.05 \mathrm{sec}+$ (P-wave travel time) $\times 0.01$. 


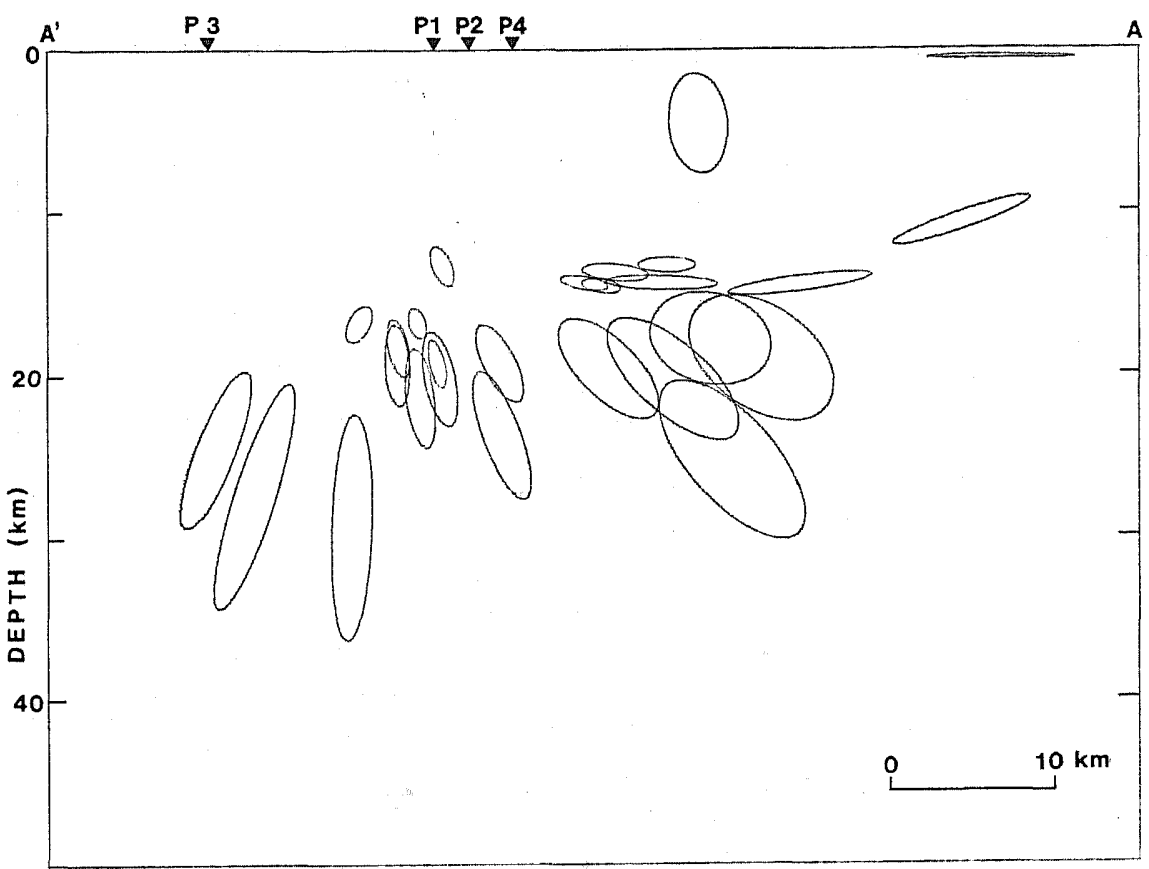

Fig. 10(b)

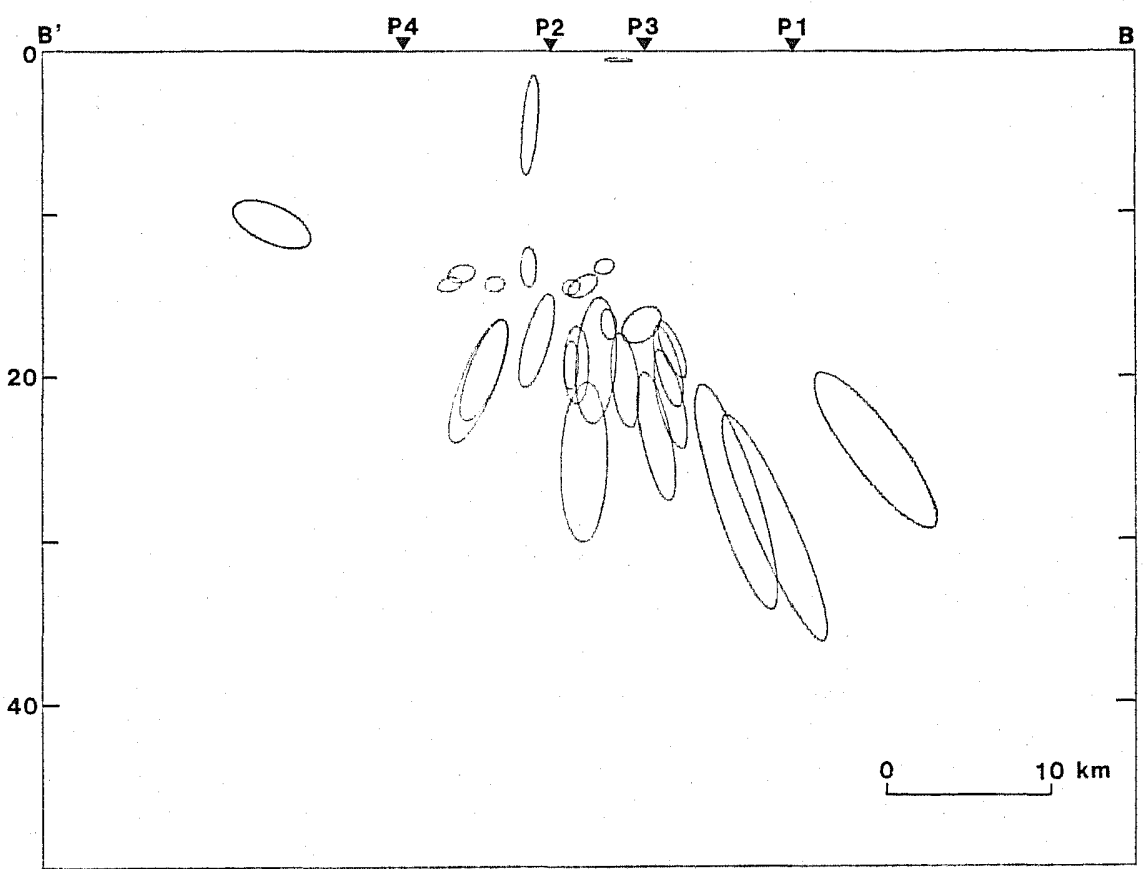

Fig. $10(c)$ 


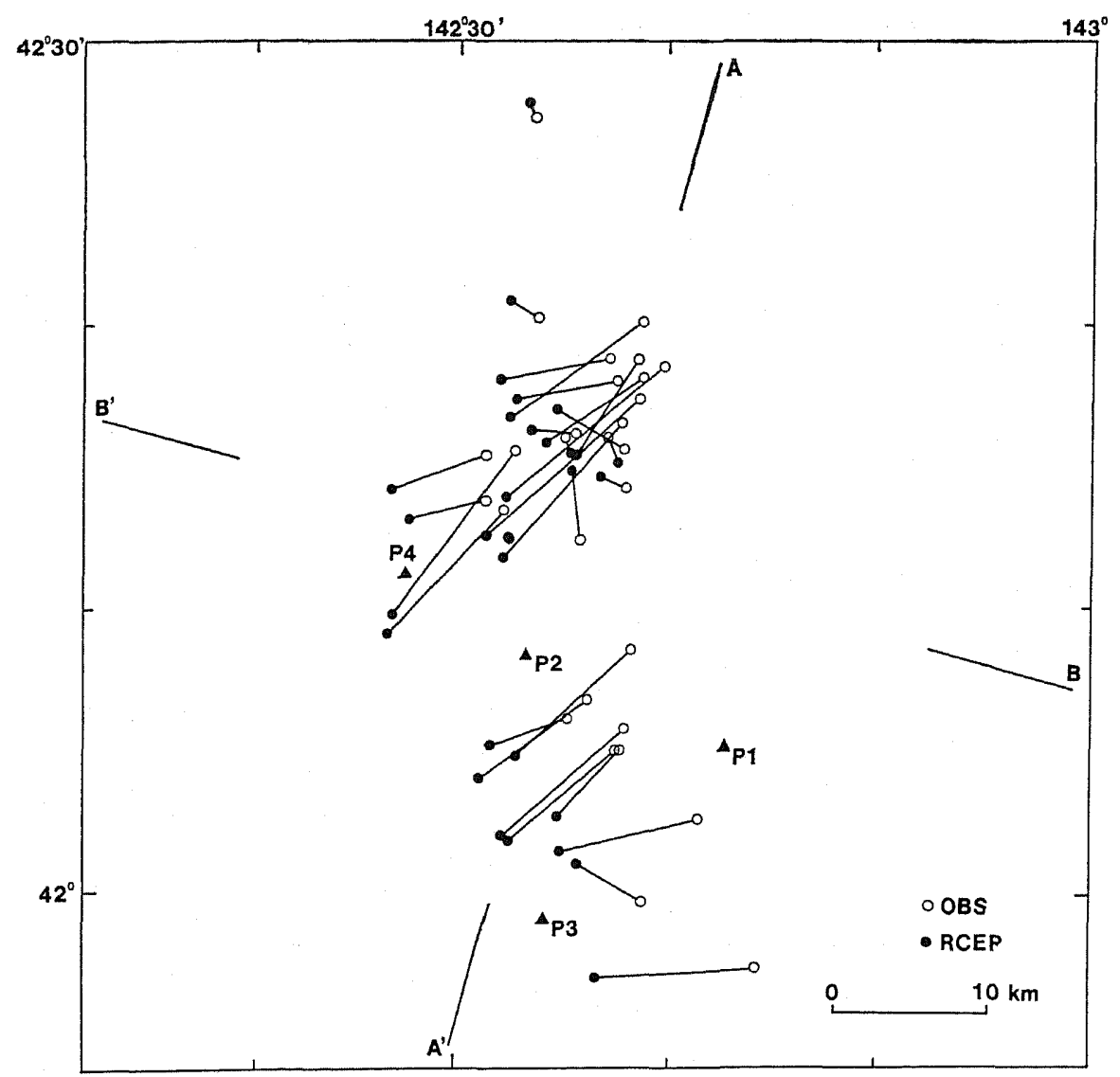

Fig. 11(a)

Fig. 11. Comparison between hypocenters by OBS network and those by RCEP. (a) Horizontal section.

(b) Vertical section $\left(A-A^{\prime}\right)$.

(c) Vertical section $\left(B-B^{\prime}\right)$.

\subsection{Aftershock distribution}

Figure 9 shows the 221 hypocenters determined from the OBS data. The estimation errors of each aftershock location were evaluated from the covariance matrix constructed in the process of the hypocenter determination (MATSU'URA and Hirata, 1982). In Fig. 10, error ellipses of hypocentral parameters are presented for 30 earthquakes. In the outside of the OBS network, the estimation errors of hypocenter are comparable to the probable errors of the initial guess. This means that the OBS data resolved poorly the hypocentral parameters outside the OBS network, and the determined aftershock locations strongly depend on the adopted initial guesses. Within the OBS network, on the other hand, the estimation errors are 1-2 km for epicenter, and 1-4 km for focal depth. In this region, the resolution of hypocenter is considerably high in comparison with that outside the OBS network. 


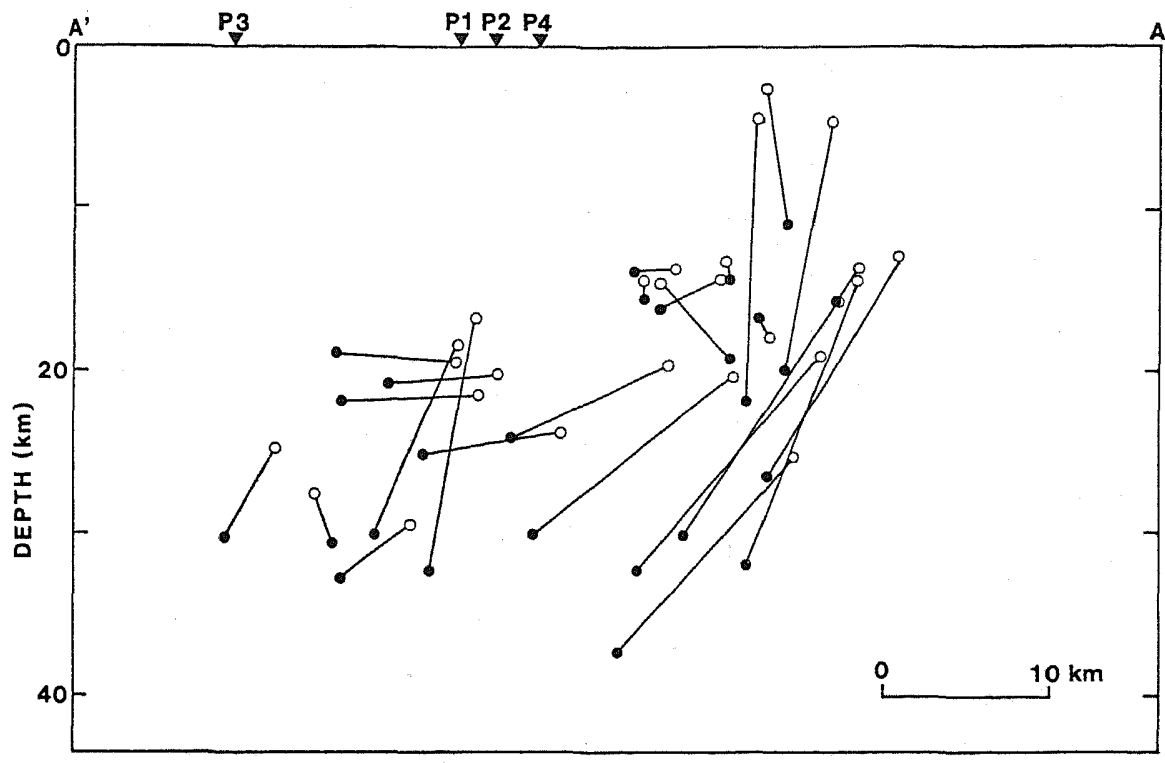

Fig. 11(b)

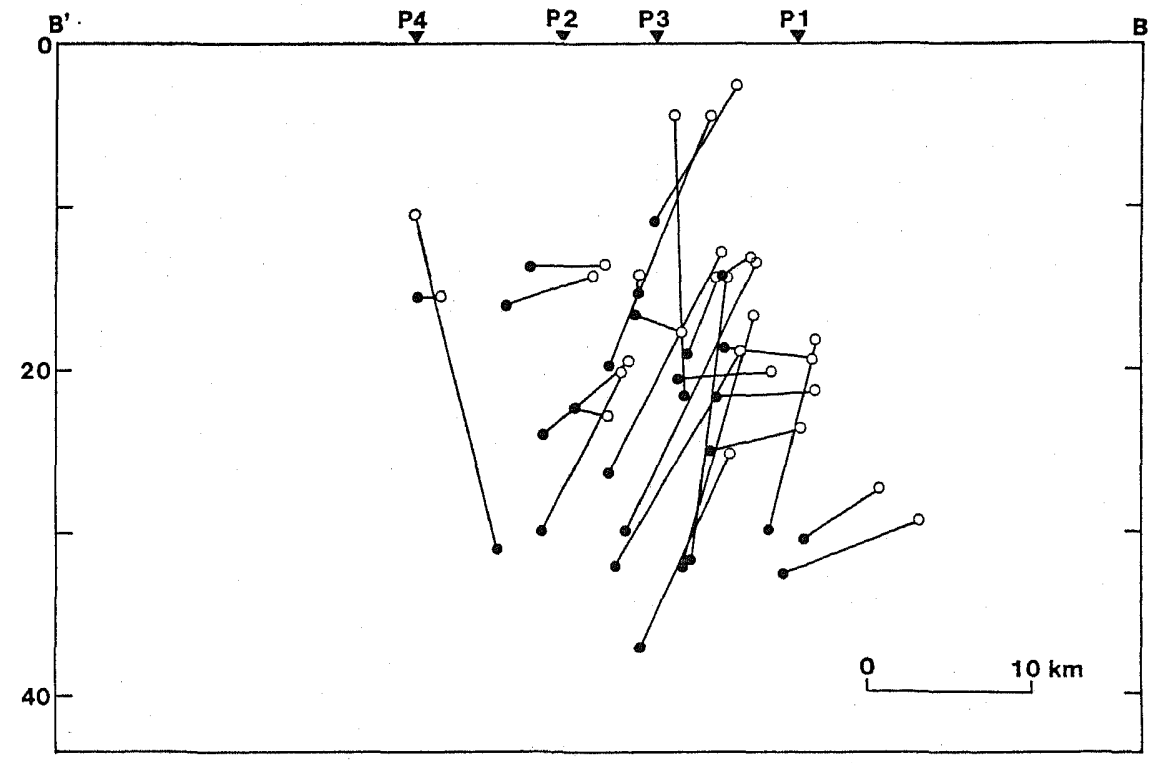

Fig. 11(c)

The epicenter map (Fig. 9(a)) shows that the aftershock activity near the main shock was relatively low during the OBS observation. The events located south of the station P2 are concentrated in an area extending to the southeast. 
Table 2. Locations of land stations.

\begin{tabular}{lccc}
\hline Station & Latitude $(\mathrm{N})$ & Longitude $(\mathrm{E})$ & Height $(\mathrm{m})$ \\
\hline HOU & $42^{\circ} 15.4^{\prime}$ & $142^{\circ} 35.7^{\prime}$ & 30 \\
KWK & $42^{\circ} 19.0^{\prime}$ & $142^{\circ} 43.1^{\prime}$ & 80 \\
K W & $42^{\prime} 19.3^{\prime}$ & $142^{\circ} 31.7^{\prime}$ & 100 \\
I K D & $42^{\circ} 11.2^{\prime}$ & $142^{\circ} 45.2^{\prime}$ & 175 \\
KMU & $42^{\circ} 14.3^{\prime}$ & $142^{\circ} 58.0^{\prime}$ & 185 \\
MSN & $42^{\circ} 25.4^{\prime}$ & $142^{\circ} 32.4^{\prime}$ & 100 \\
S P P & $42^{\circ} 23.1^{\prime}$ & $142^{\circ} 17.3^{\prime}$ & 40 \\
\hline
\end{tabular}

Table 3. Adopted station corrections.

\begin{tabular}{ccc}
\hline Station & $\begin{array}{c}\text { Relative correction } \\
\left(\Delta t_{\mathrm{c}}-J t_{\mathrm{c}} \mathrm{HOV}_{\mathrm{Hov}}(\mathrm{sec})\right)\end{array}$ & $\begin{array}{c}\text { Station correction } \\
\left(\Delta t_{\mathrm{c}}(\mathrm{sec})\right)\end{array}$ \\
\hline HOU & - & $\Delta t_{\mathrm{d}}$ \\
KWK & 0.0 & $\Delta t_{\mathrm{d}}$ \\
K W & 0.0 & $\Delta t_{\mathrm{d}}$ \\
I K D & 0.6 & $0.6+\Delta t_{\mathrm{d}}$ \\
KMU & -0.2 & $-0.2+\Delta t_{\mathrm{d}}$ \\
MSN & 0.0 & $\Delta t_{\mathrm{d}}$ \\
S P P & 1.2 & $1.2+\Delta t_{\mathrm{d}}$ \\
\hline
\end{tabular}

The northern part of the aftershock area, on the other hand, extends northeastward into the land. However, the northern edge of the aftershock area is obscure only from the analysis of the OBS data. In the vertical cross sections (Figs. 9(b) and 9(c)), the obtained hypocenters show a complicated distribution. Most of the aftershocks are located in a depth range of $10-30 \mathrm{~km}$. We can find concentration of events at the depth of $20-30 \mathrm{~km}$ in the southern edge of the aftershock area, although the corresponding estimation error is considerably large. In Fig. 11, the aftershock locations by the OBS network are compared with the initial guesses (the hypocenters by RCEP). The epicenters determined by the OBS network are located $5-15 \mathrm{~km}$ northeast of those determined by RCEP. Figures 11(b) and 11 (c) show that the systematic difference in focal depth is $10-20 \mathrm{~km}$.

\section{Aftershock Distribution Determined from $O B S$ and Land Data}

In the previous section, the aftershock distribution of the Urakawa-Oki earthquake was determined from the OBS data. However, reliable hypocentral parameters were not obtained in the outside of the OBS network. This section presents the aftershock distribution determined by combining the OBS and land data. The seismograph network used in the analysis consists of four OBS's, two permanent stations of RCEP and five temporary land stations deployed by Moriya et al. (1983a, b), which cover the entire aftershock area (Fig. 3 and Table 2). 


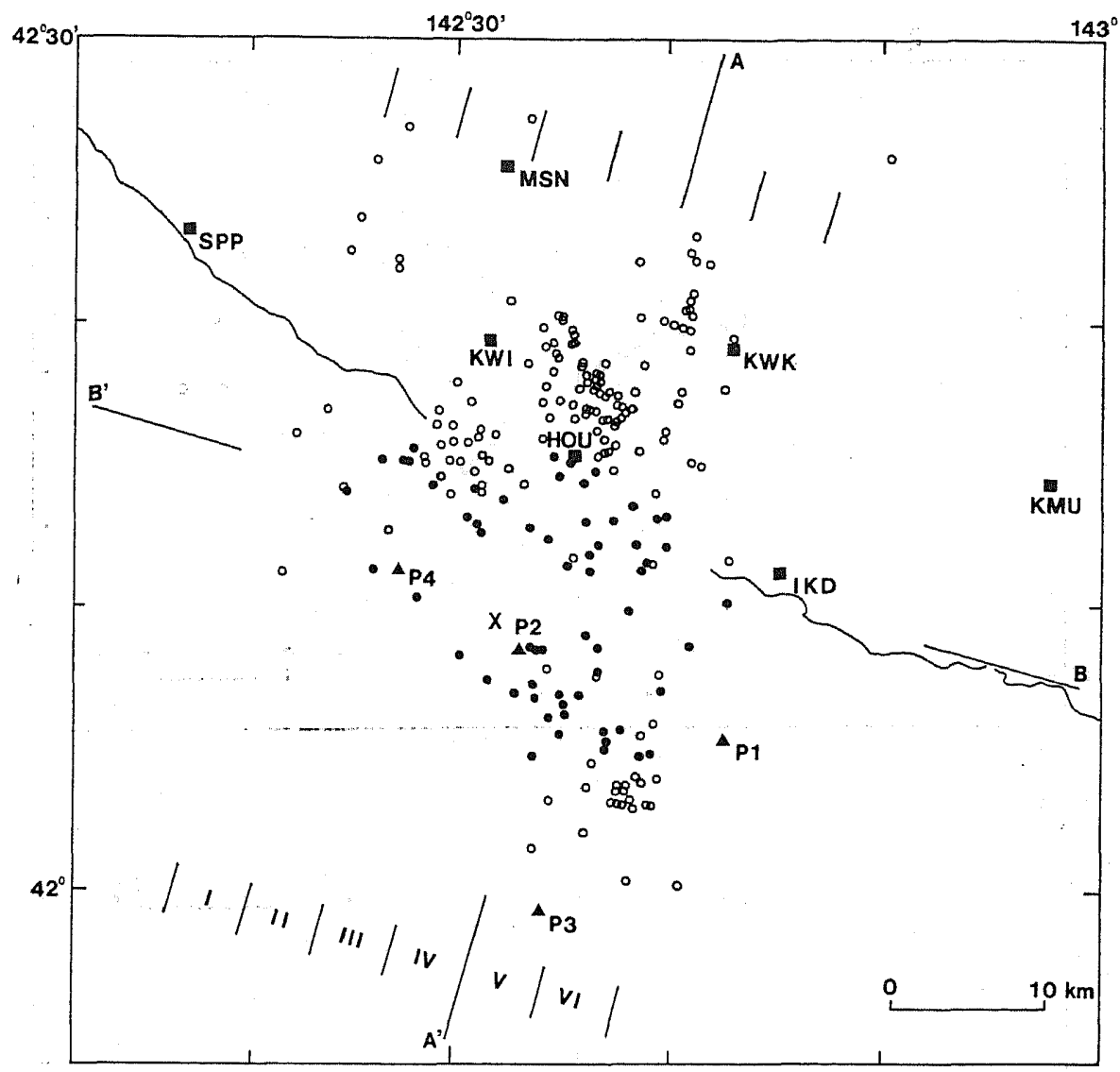

Fig. 12(a)

Fig. 12. Aftershock distribution determined from OBS and land data. In the computation, $\Delta t_{\mathrm{d}}$ was taken as $-0.3 \mathrm{sec}$. (a) Epicenter map. The OBS and land stations are shown by solid triangles and squares, respectively. Solid circles denote events located on a dipping plane in the southern part of the aftershock area (see Fig. 12 (b)). The hypocenter distributions in divided sections (I-VI) are shown in Fig. 15. (b) Hypocenter distribution in vertical section with strike of $\mathrm{N} 15^{\circ} \mathrm{E}-\mathrm{S} 15^{\circ} \mathrm{W}\left(\mathrm{A}-\mathrm{A}^{\prime}\right)$. The events in the southern part of the aftershock area are located on a dipping plane as shown by the shadded region. (c) Hypocenter distribution in vertical section with strike of $\mathrm{S} 75^{\circ} \mathrm{E}-\mathrm{N} 75^{\circ} \mathrm{W}\left(\mathrm{B}-\mathrm{B}^{\prime}\right)$.

\subsection{Station corrections}

As was described in Sec. 3, the P-wave velocity is considered to vary laterally in the aftershock region of the Urakawa-Oki earthquake. In the hypocenter determination, the lateral heterogenity of the velocity structure may cause systematic estimation errors. In order to remove such bias, we applied station corrections to the arrival time data.

In the following analysis, we adopt the same velocity structure model as in 


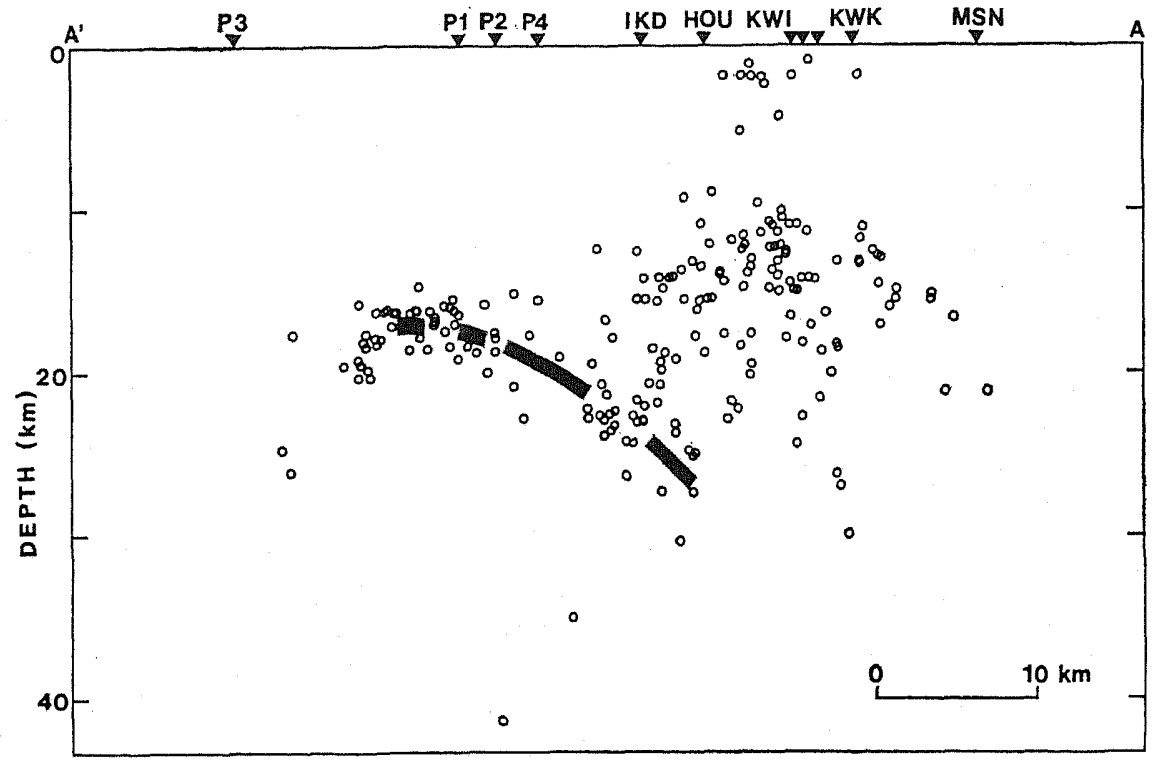

Fig. 12(b)

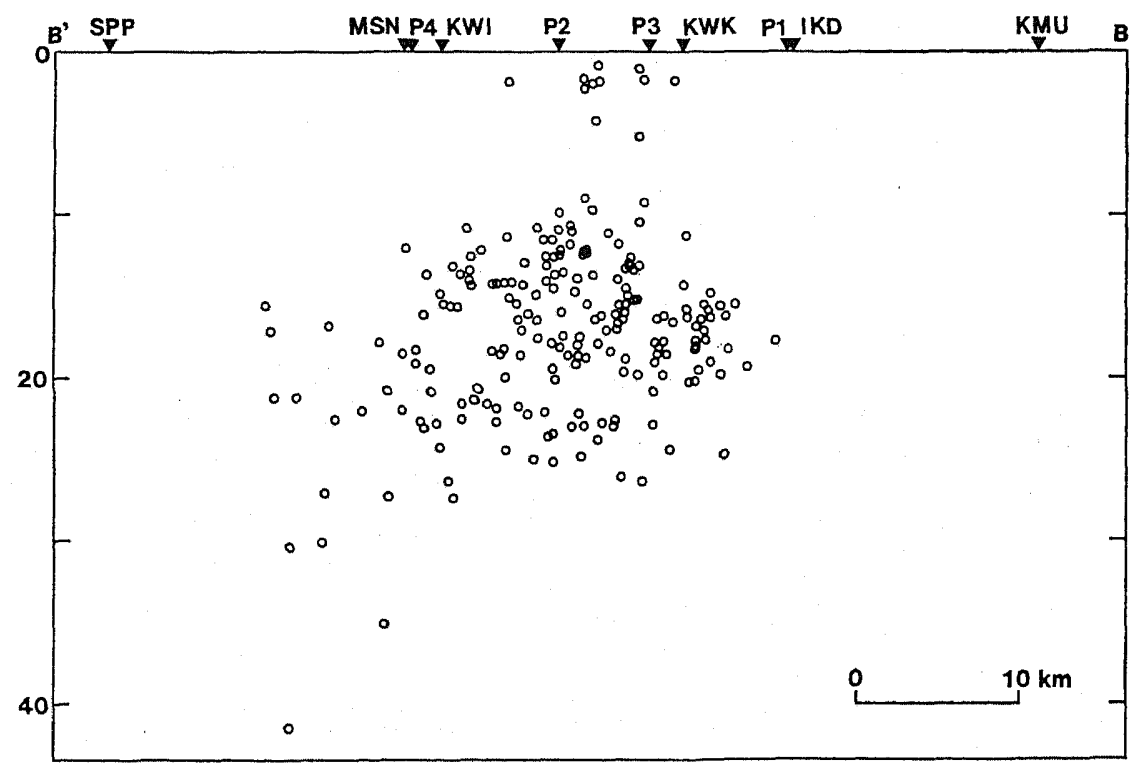

Fig. 12(c) 


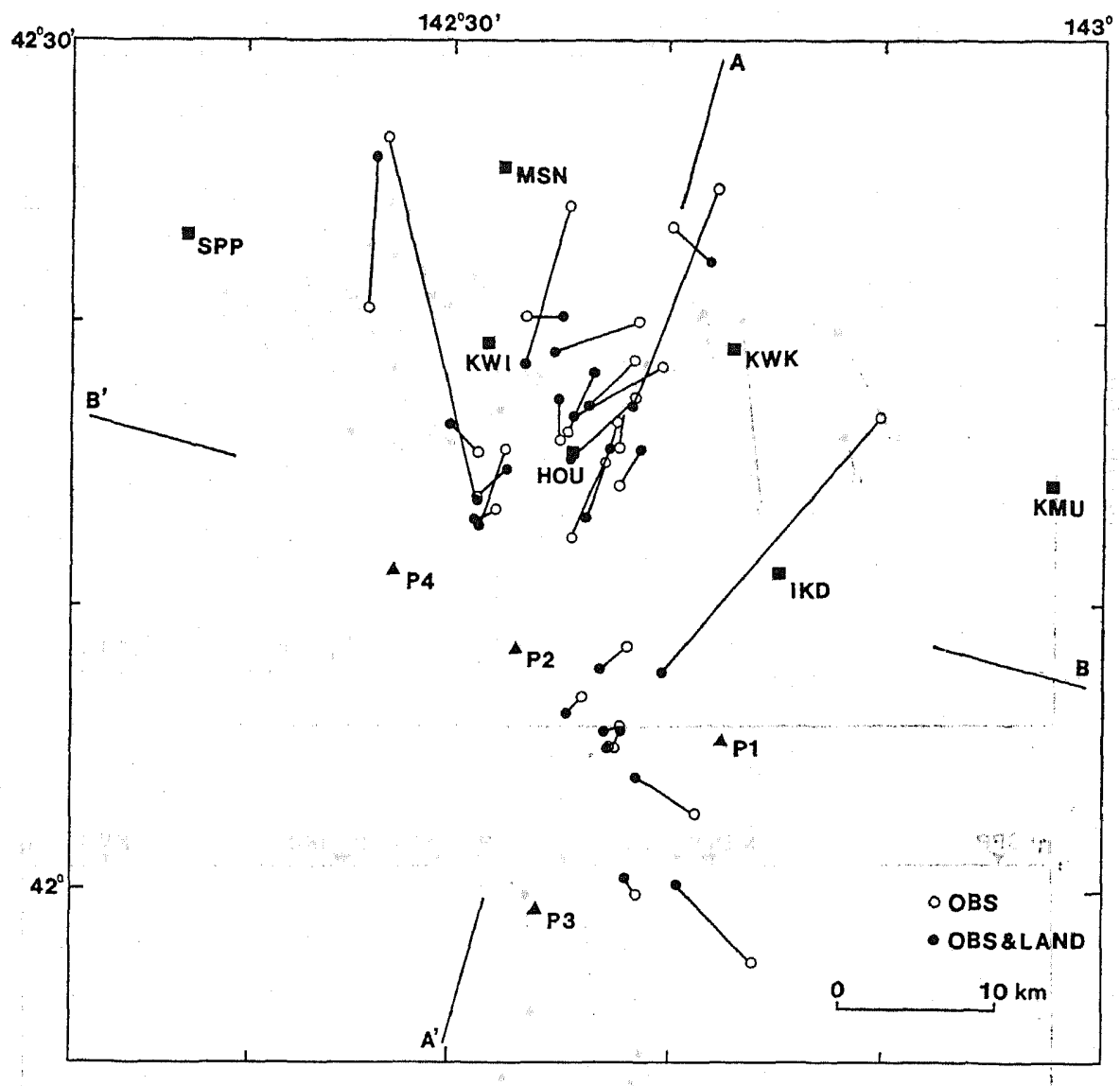

Fig. 13(a)

Fig. 13. Comparison between hypocenters by combined OBS and land network and those by OBS network. (a) Horizontal section. (b) Vertical section $\left(A-A^{\prime}\right)$. (c) Vertical section $\left(\mathrm{B}^{-} \mathrm{B}^{\prime}\right)$.

Sec. 3. Because this model represents the crustal structure in the sea area, station corrections were applied to the arrival time data at the land stations (Table 3). The second column in Table 3 shows the relative corrections with respect to the station correction at $\mathrm{HOU}$, which were estimated from the upper crustal structure in Hidaka by FUJII and MORIYA (1983). It should be noted that the large values of correction at SPP and IKD represent the existence of a thick sedimentary layer. Each station correction, $\Delta t_{\mathrm{c}}$, is given as a sum of the relative correction and the station correction at $\mathrm{HOU}\left(\Delta t_{\mathrm{d}}\right)$. We determined aftershock locations for several representative cases with different $\Delta t_{\mathrm{d}}$ since the crustal structure in the aftershock region is not known enough to estimate the appropriate value of $\Delta t_{\mathrm{d}}$. 


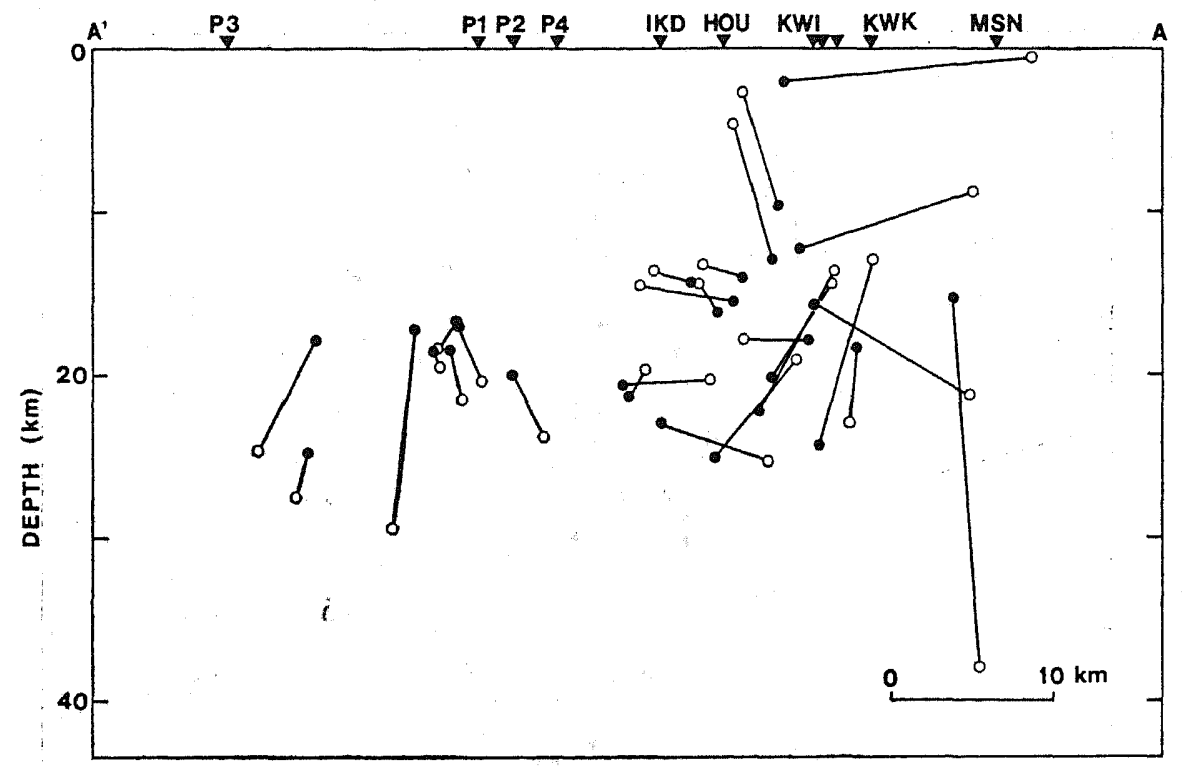

Fig. 13(b)

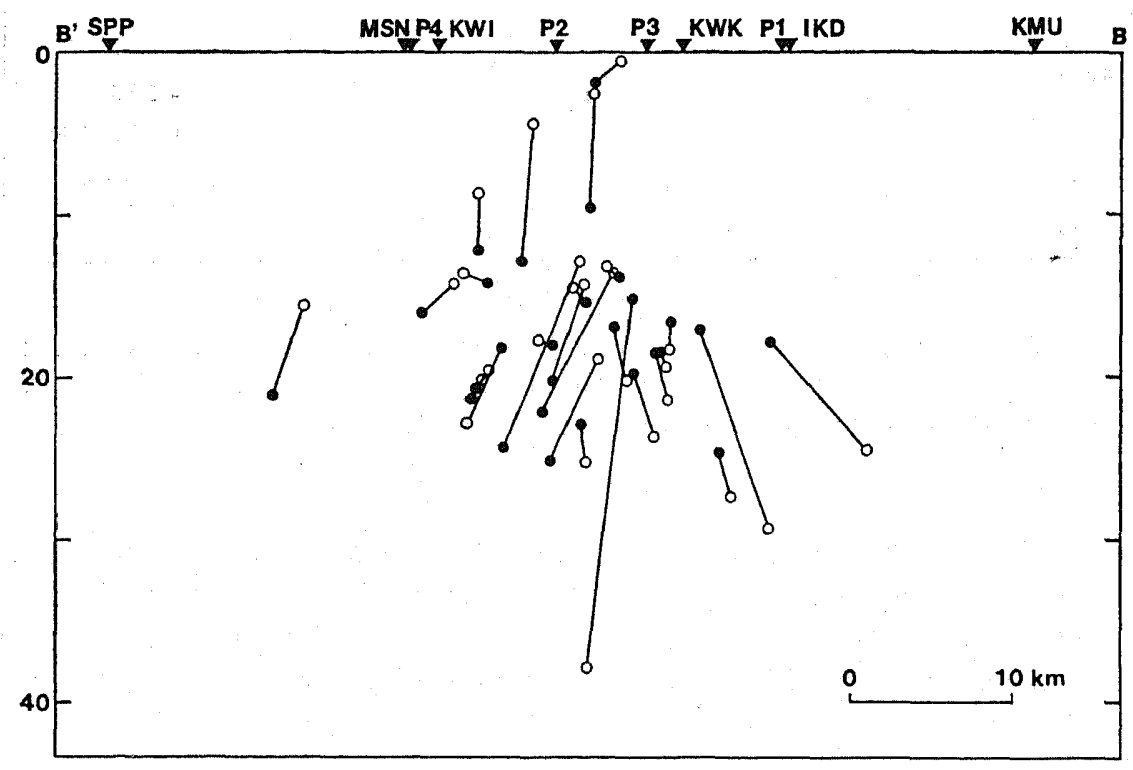

Fig. 13(c)

\subsection{Aftershock distribution}

We selected 253 aftershocks of $M_{\mathrm{RCEP}} \geq 2.0$, and determined their locations from $\mathrm{P}$-wave data at 11 stations. In the computation, the initial guesses and 
their probable errors were taken to be the same as those in the case of Fig. 9. The error in the arrival time was assumed to be $0.05 \mathrm{sec}+(\mathrm{P}$-wave travel time $) \times 0.01$ for the OBS station. Because we adopted the velocity structure in the sea area, the error in the land data was taken as relatively large value of $0.20 \mathrm{sec}+(\mathrm{P}$-wave travel time) $\times 0.01$.

Figure 12 shows the 234 aftershock locations calculated for $\Delta t_{d}=-0.3 \mathrm{sec}$. In the entire aftershock region, the estimation errors of hypocenter are less than 1-2 $\mathrm{km}$ for epicenter and less than $1-3 \mathrm{~km}$ for focal depth. This means that the arrival time data used in the analysis resolved well the hypocentral parameters. In Fig. 13, 30 hypocenters for $\Delta t_{\mathrm{d}}=-0.3 \mathrm{sec}$ are compared with those determined by the OBS data. When the land data are included in the computation, the epicenter outside the OBS network is shifted by $5-10 \mathrm{~km}$. Within the OBS network, on the other hand, the difference in aftershock location is relatively small.

Figure 14 shows the dependence of distribution pattern on $\Delta t_{\mathrm{d}}$. In each figure, the hypocenters are projected onto the vertical plane with the same strike direction as in Fig. 12(b), which corresponds to the case of $\Delta t_{\mathrm{d}}=-0.3 \mathrm{sec}$. The gross features of the aftershock distribution are not affected by the change of $\Delta t_{\mathrm{d}}$. However, in the cases of $\Delta t_{\mathrm{d}}=-0.9$ and $-1.2 \mathrm{sec}$, about 10 earthquakes occurring beneath the sea were relocated within the unconsolidated sedimentary layer.

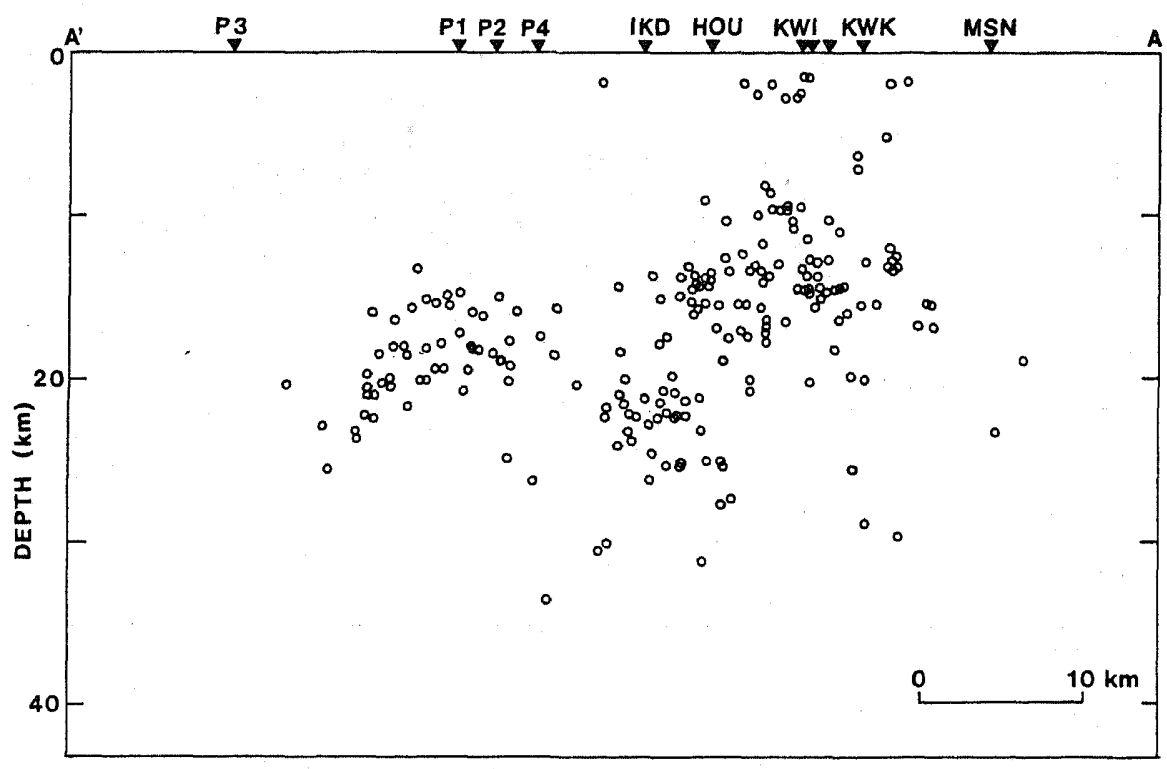

Fig. 14(a)

Fig. 14. Dependence of aftershock distribution on $\Delta t_{\mathrm{d}}$. The hypocenter distribution was projected onto the vertical plane with the same strike as that in Fig. 13(b). (a) No corrections. $\Delta t_{\mathrm{d}}=-1.2 \mathrm{sec}$.

(b) $\Delta t_{\mathrm{d}}=0.0 \mathrm{sec}$.

(c) $\Delta t_{\mathrm{d}}=-0.6 \mathrm{sec}$.

(d) $\Delta t_{\mathrm{d}}=-0.9 \mathrm{sec}$. 


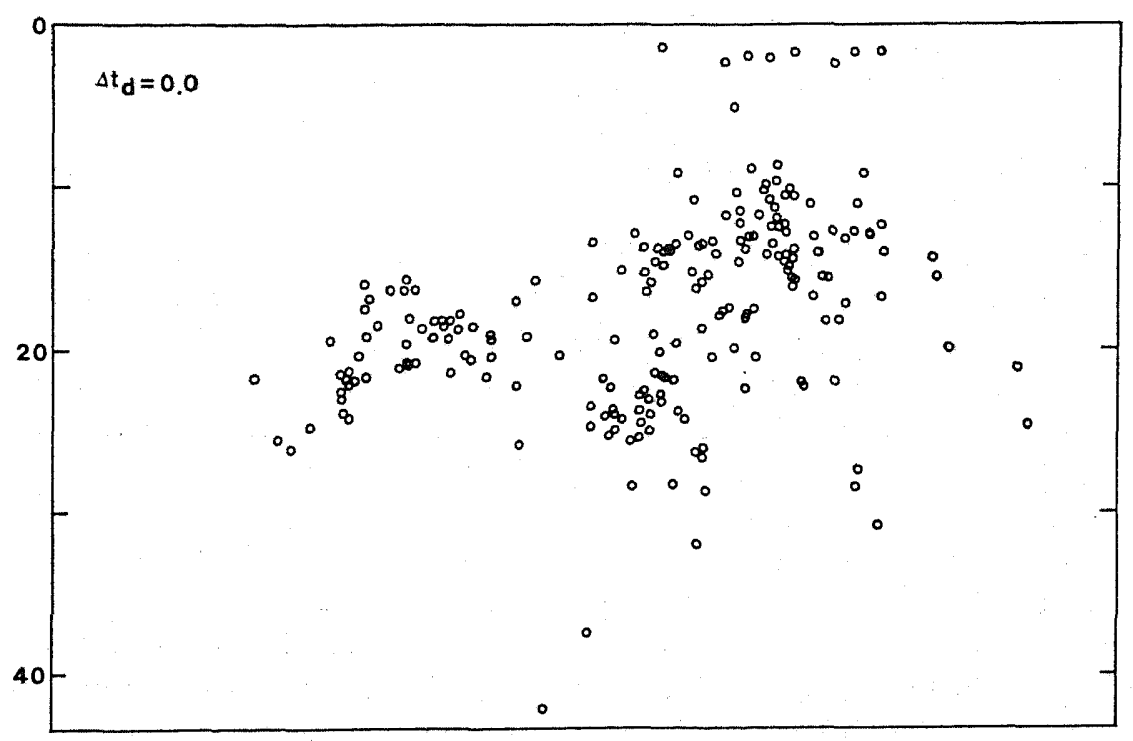

Fig. 14(b)

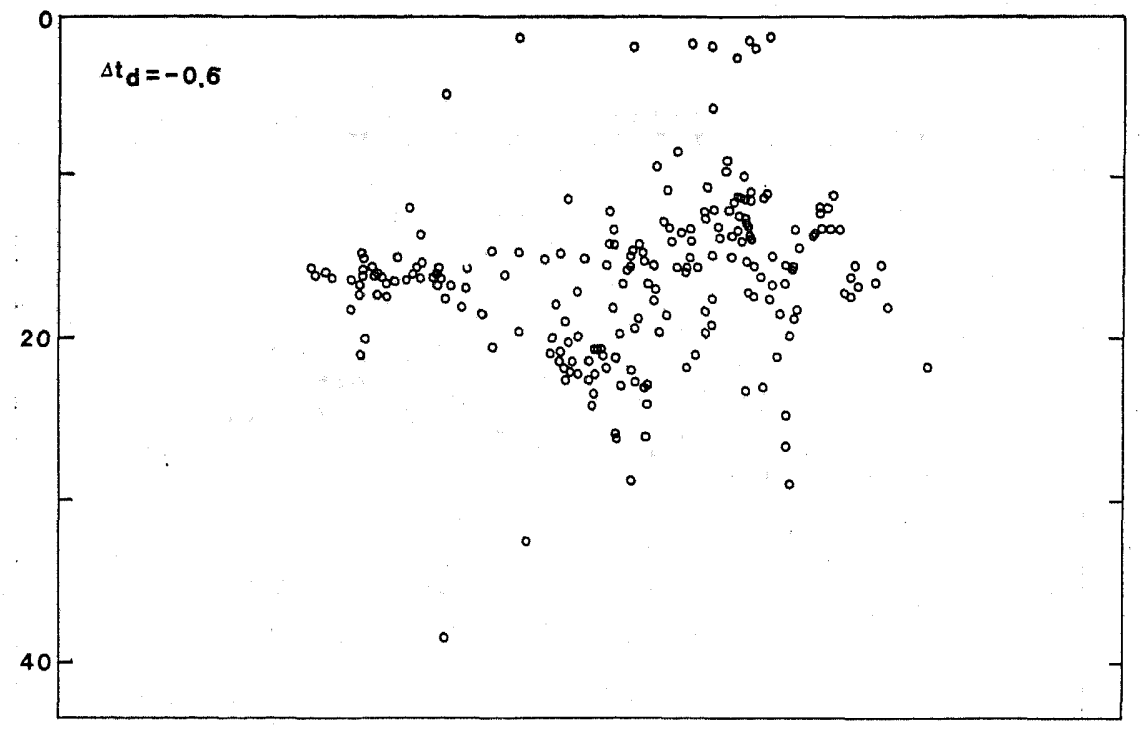

Fig. 14(c)

This result seems unrealistic. In general, O-C residual of the $\mathrm{P}$-wave arrival time becomes large in the range of $\Delta t_{\mathrm{d}} \leq-0.9 \mathrm{sec}$.

In the following part of this section, we describe several important features of the aftershock distribution calculated for $\Delta t_{\mathrm{d}}=-0.3 \mathrm{sec}$. From the epicenter map (Fig. 12(a)), it is found that the aftershock area extends to the vicinity of the 


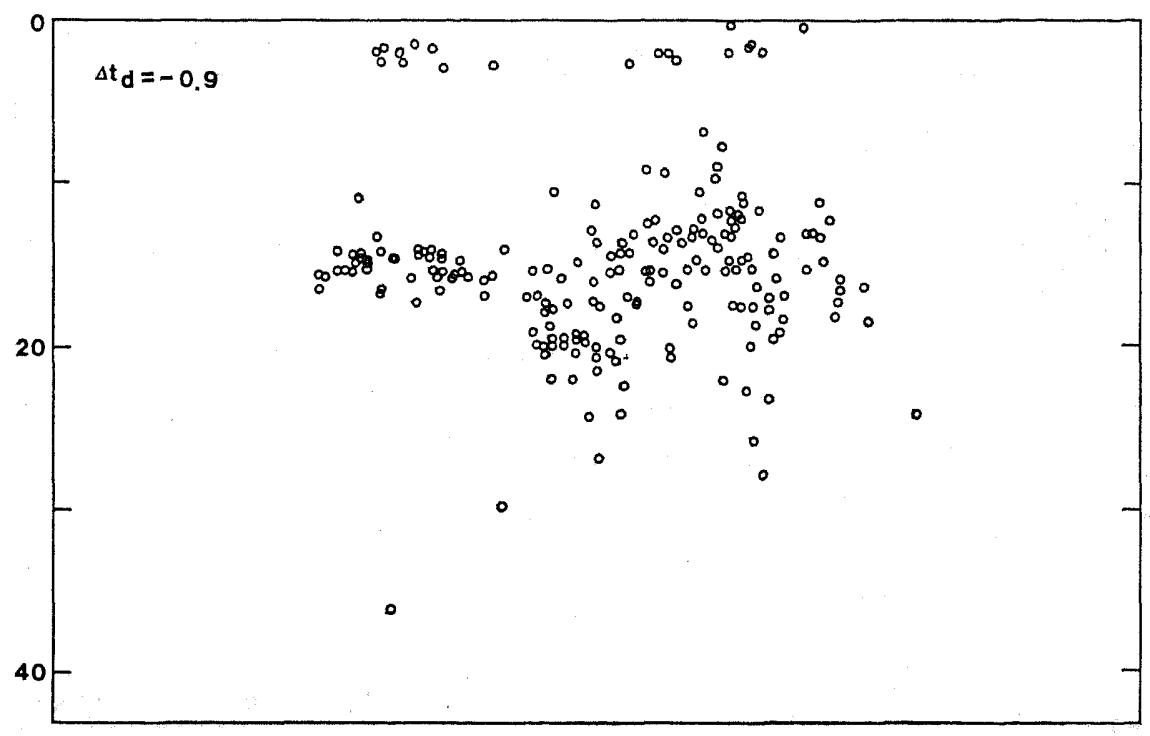

Fig. 14(d)

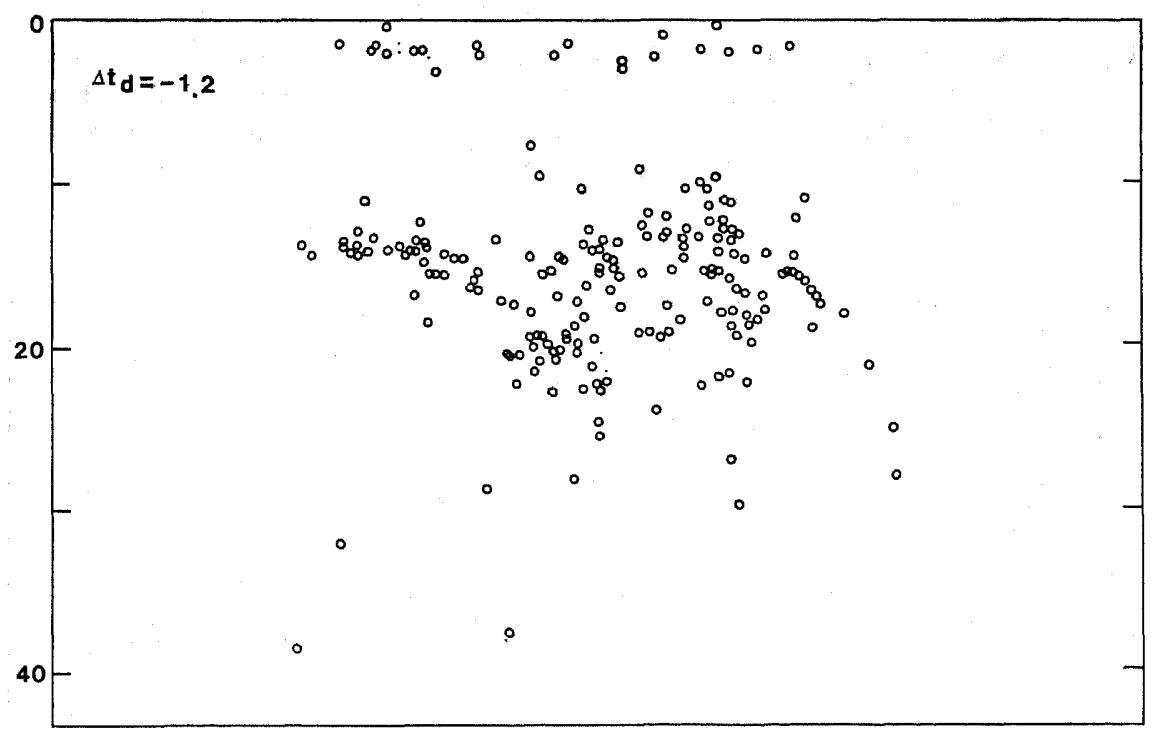

Fig. 14(e)

station KWK, which is located $15 \mathrm{~km}$ inland from the coast line. The southern edge of the aftershock area, on the other hand, is about $10 \mathrm{~km}$ south of P1. Hence, the dimensions of aftershock area are estimated roughly as $35 \mathrm{~km} \times 25 \mathrm{~km}$. The relocated events are concentrated in the northern part and southern edge of the aftershock area, but not in the vicinity of the main shock. Such a distribution 


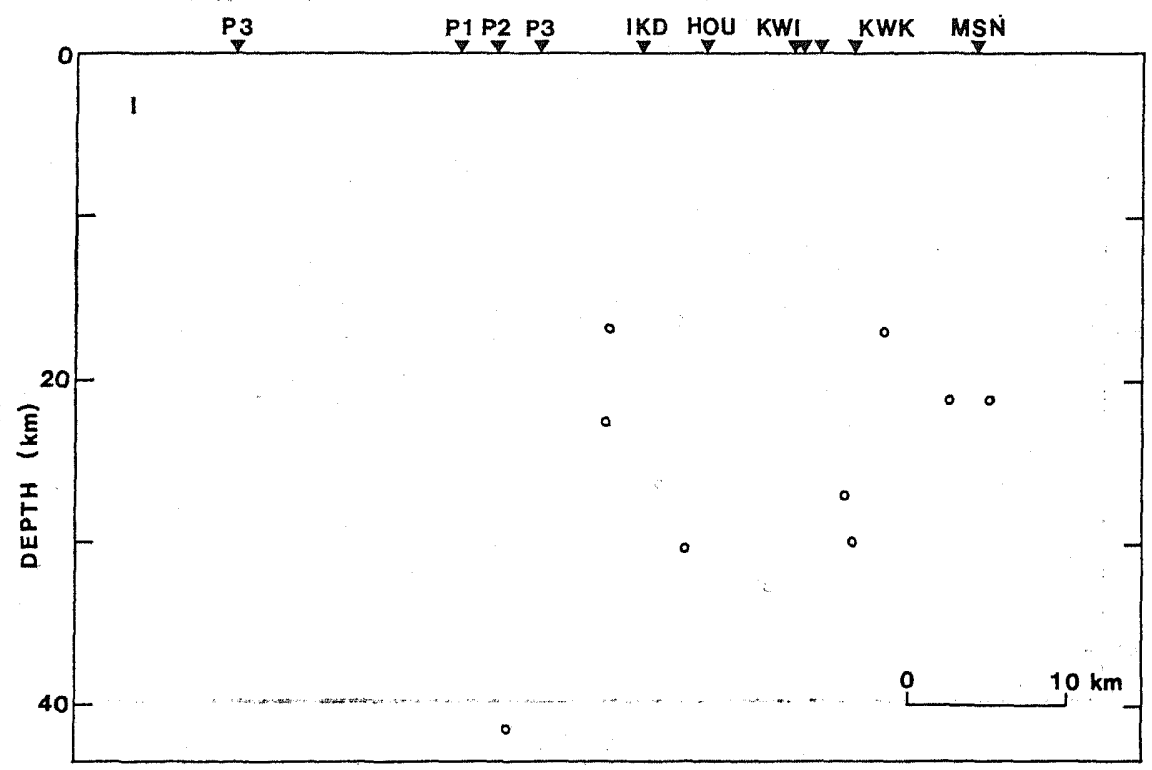

Fig. 15(a)

Fig. 15. Subdivided aftershock distribution. The hypocenter distribution was shown in detail by dividing the aftershock area into six sections (see Fig. 13(a)). Hypocenters in each section are projected onto the vertical plane with strike of $N 15^{\circ} \mathrm{E}$ (right) $-\mathrm{S} 15^{\circ} \mathrm{W}$ (left). (a) Section I. (b) Section II. (c) Section III. (d) Section IV. (e) Section V. (f) Section VI.

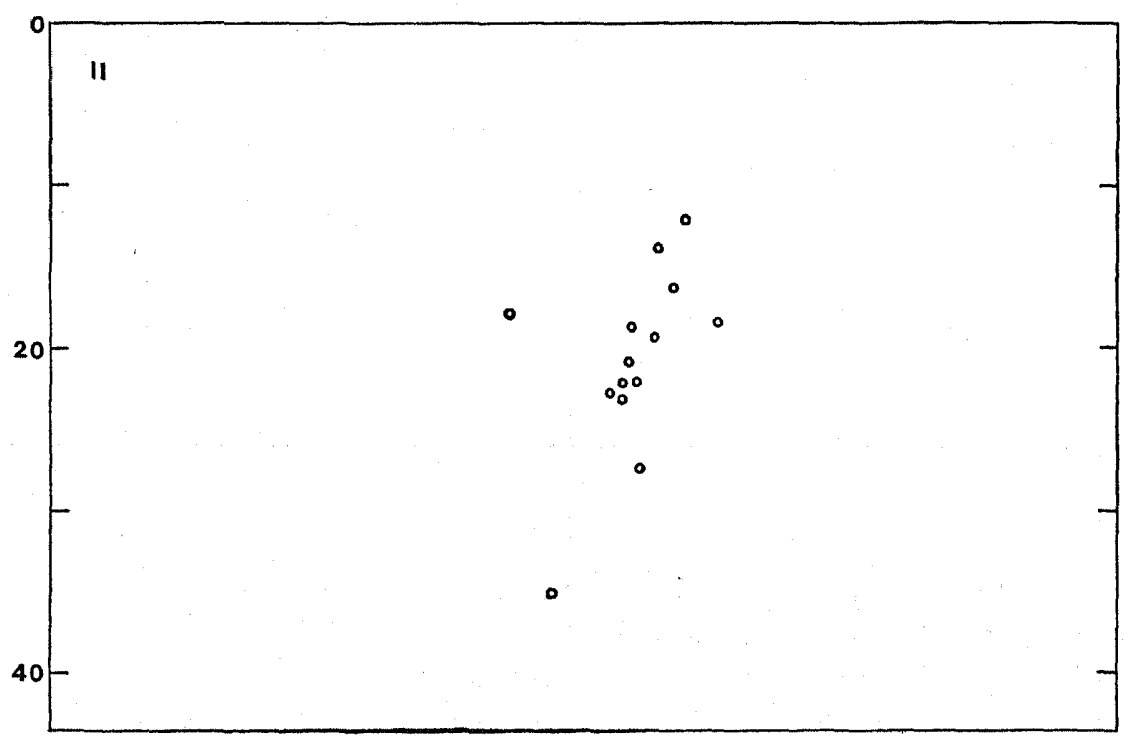

Fig. 15(b) 


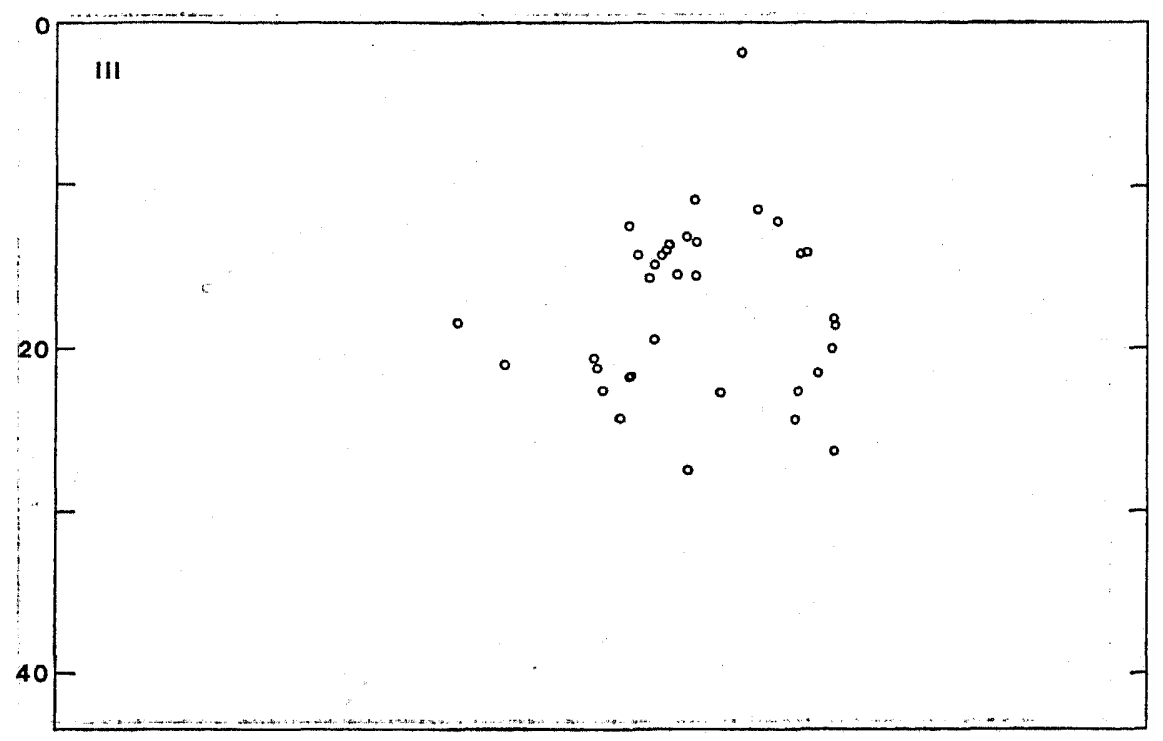

Fig. $15(\mathrm{c})$

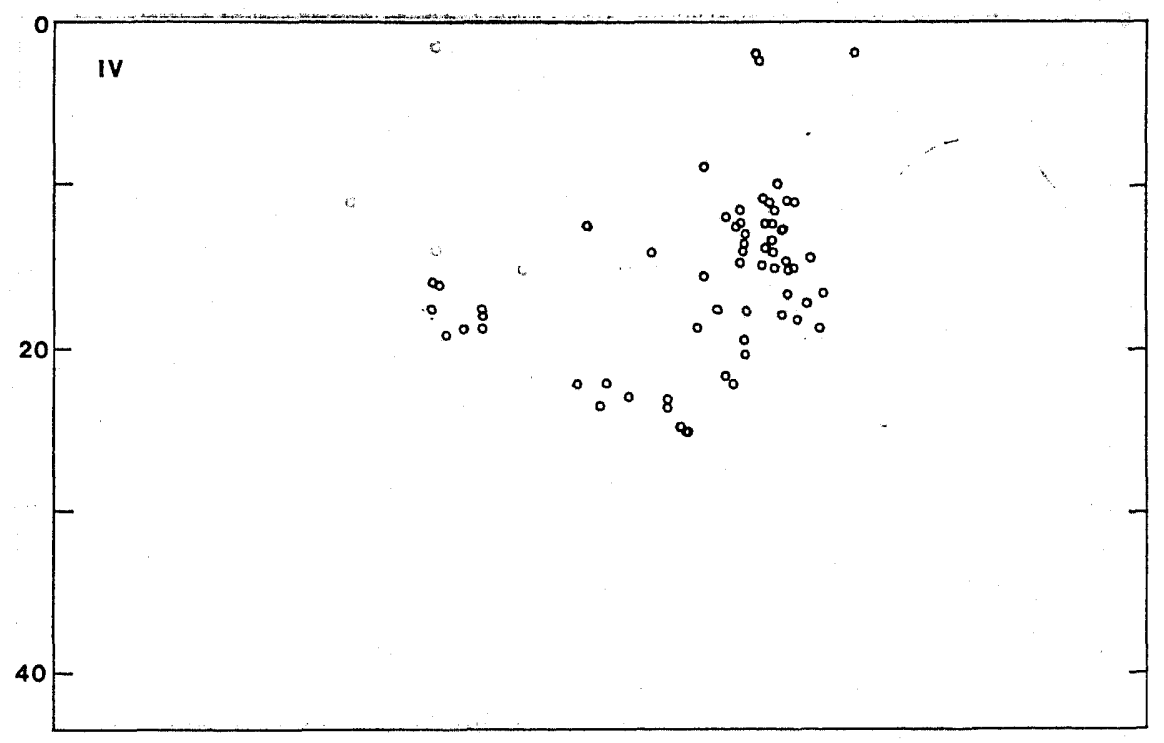

Fig. 15(d)

pattern was also found in the analysis of the OBS data (see Fig. 9). Figures 12(b) and 12(c) show that most of the aftershocks occurred in a depth range of 10-30 $\mathrm{km}$.

In order to clarify the fine structure of the aftershock distribution, we divided 


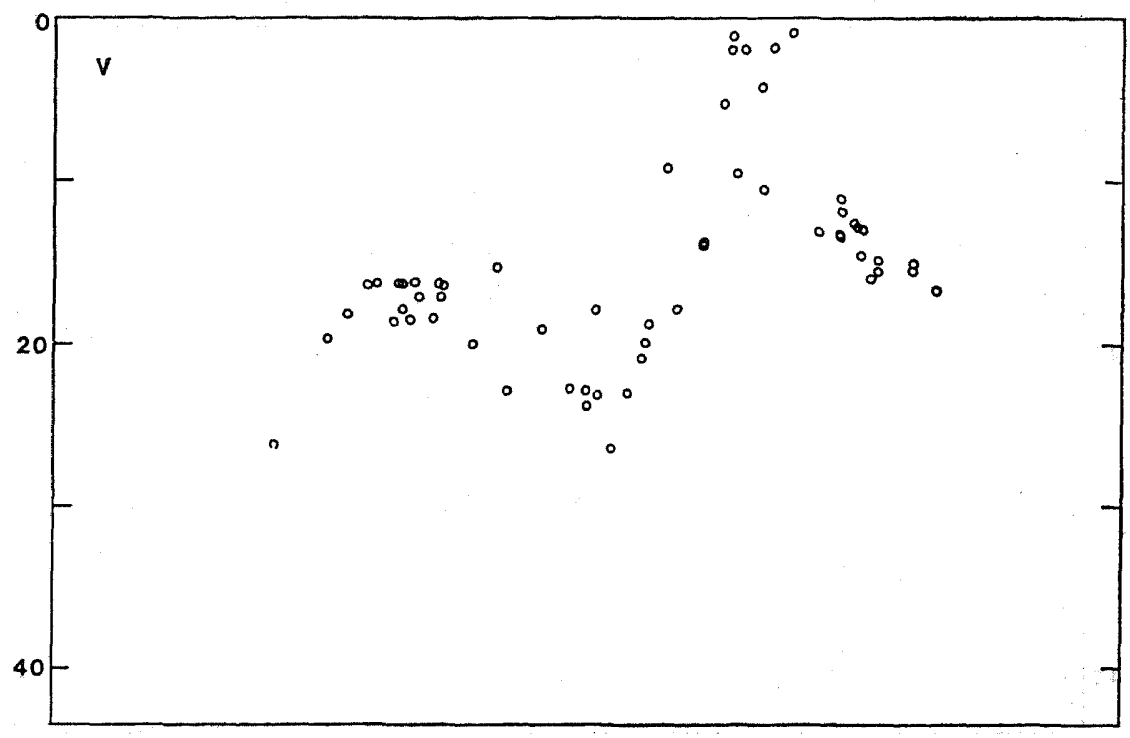

Fig. 15(e)

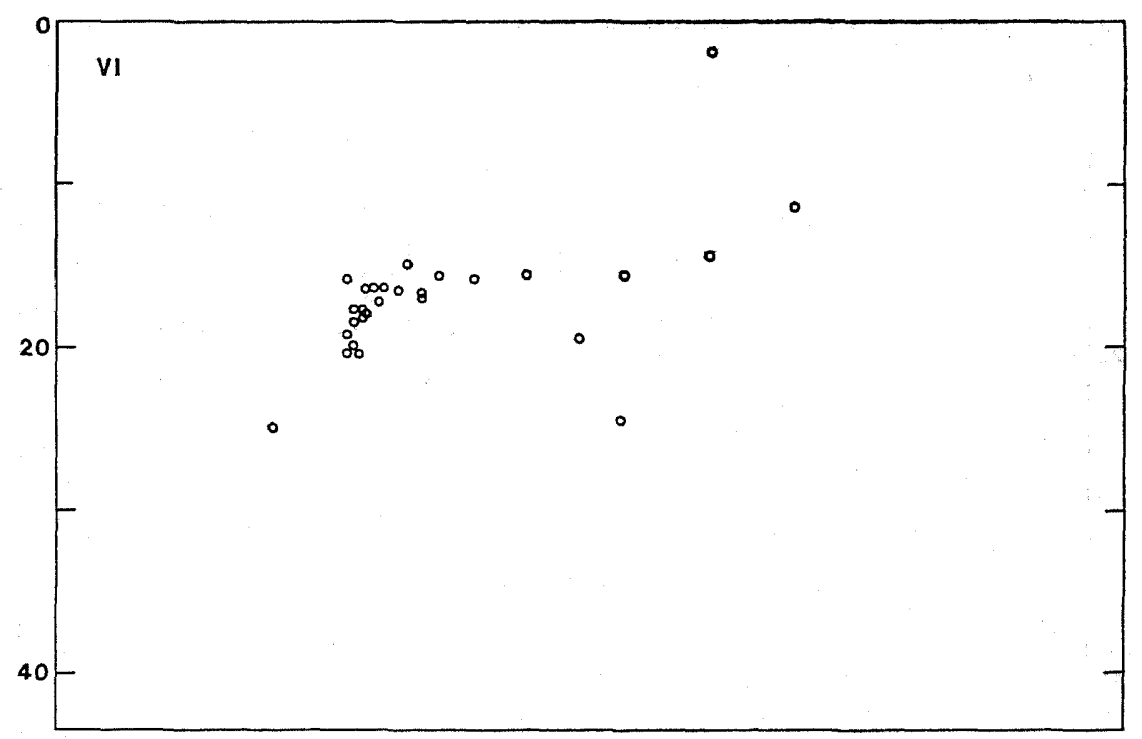

Fig. 15(f)

the aftershock area into six sections as shown in Fig. 12(a), and investigated hypocenter patterns in detail. In Fig. 15, aftershock locations in each section are projected onto a vertical plane with the same strike as in Fig. 12(b). In sections III, IV, V, and VI, the events in the southern part of the aftershock area delineate 
a plane dipping northward with an angle of 20-30. This trend of events is shown by the shaded region in Fig. 12(b). In the epicenter map (Fig. 12(a)), we denoted the events on the dipping plane by solid circles. It is found that the dipping plane spreads in a considerably wide area of $20-25 \mathrm{~km} \times 10-15 \mathrm{~km}$. In sections IV and $\mathrm{V}$, we find another trend of events inclining southward with a high angle of $60-70^{\circ}$. The events in this group are located on a plane with a relatively narrow area of $10 \mathrm{~km} \times 10-15 \mathrm{~km}$. These two remarkable trends strongly suggest the existence of a pair of conjugate fault planes. Actually, the dip directions of the two trends are consistent with the focal mechanism of the Urakawa-Oki earthquake by TAKEO et al. (1983).

\section{Discussions and Conclusions}

The Urakawa-Oki earthquake $(M=7.1)$ took place off Urakawa, Hokkaido, Japan, on March 21, 1982. After this event, a large number of aftershocks were observed at land seismograph stations in Hokkaido. According to a preliminary report by the Research Center for Earthquake Prediction (RCEP) of Hokkaido University, about two thirds of the aftershocks occurred in the sea area.

Eight days after the Urakawa-Oki earthquake, we deployed four OBS's off Urakawa for the purpose of precise investigation of the aftershock activity. During an observation period from March 29 to April 6, the OBS network detected more than 4,500 events. We estimated magnitudes of these events from signal duration times. The obtained magnitudes ranged from -2.0 to 5.0. Among the detected aftershocks, the events with $M \geq 2.0$ were recorded clearly both by the OBS's and the land stations located around the aftershock area.

The aftershock distribution of the Urakawa-Oki earthquake was investigated in detail on the basis of the OBS and land observations. The hypocenter determination was carried out for about 250 aftershocks with $M \geq 2.0$ by using an inverse method. As the initial guesses of the computation, we used hypocenters and origin times determined by the RCEP land network.

The crustal structure in the aftershock region of the Urakawa-Oki earthquake is not known precisely enough. Several seismological investigations suggest that the P-wave velocity varies laterally in the aftershock area (AsANo et al., 1979; TAKanAmI, 1982; FurII and MoriYa, 1983; MrYamaCHI and MoriYa, 1983). As a first step of the analysis, we determined aftershock locations only from Pwave data at the OBS stations. In the computation, we used the velocity structure off Hidaka determined by ASANO et al. (1979). Most of the aftershocks were relocated at depths shallower than $30 \mathrm{~km}$. The events south of the main shock were concentrated in an area extending to the southeast. The northern part of the aftershock area was found to extend northeastward into the land. During the observation period, the aftershock activity was low in the vicinity of the main shock. In the analysis of the OBS data, however, reliable hypocenter was not obtained for the aftershock occurring outside the OBS network. 
Next, aftershock distribution was determined by combining the OBS and land data. The seismograph network used in the analysis consists of four OBS and seven land stations covering the entire aftershock region. The velocity structure model was taken to be the same as that in the analysis of the OBS data, and station corrections were applied to the land data. Computation of hypocenters was carried out for several cases with different sets of station correction. Examining $\mathrm{O}-\mathrm{C}$ residuals of $\mathrm{P}$-wave arrival times in each case, we estimated the appropriate values of correction.

The reliable aftershock distribution is presented in Fig. 12. In general, the accuracy of hypocenter determination was improved by adding the land data. The obtained epicenters were located in a region of $42^{\circ} 00^{\prime}-42^{\circ} 20^{\prime} \mathrm{N}$ and $142^{\circ} 25^{\prime}-$ $142^{\circ} 40^{\prime} \mathrm{E}$. The characteristic dimensions of the aftershock area were estimated as $35 \mathrm{~km} \times 25 \mathrm{~km}$. Several important features of the aftershock distribution were revealed by projecting the hypocenters onto vertical planes. In the southern part (south of $42^{\circ} 15^{\prime} \mathrm{N}$ ) of the aftershock area, the events occurred on a plane with an area of $20-25 \mathrm{~km} \times 10-15 \mathrm{~km}$ dipping $20-30^{\circ}$ northward. In the northern part, we found another trend of events which inclined southward with a high angle of $60-70^{\circ}$. The events in this group were located on a plane with a relatively small area of $10 \mathrm{~km} \times 10-15 \mathrm{~km}$. These two remarkable trends suggest the existence of two conjugate fault planes.

The fault model of the Urakawa-Oki earthquake was presented by TAKEO et al. (1983). From the analysis of the levelling data, he concluded that the fault motion of this earthquake was a reverse right-lateral slip of $0.8 \mathrm{~m}$ on a fault plane which dips $50^{\circ}$ towards $N 120^{\circ} \mathrm{W}$. The dip direction of this plane is consistent with that deduced from the hypocenter distribution in the northern part of the aftershock area. However, the geodetic measurements cover only a part of the aftershock area due to geographical limitation. Hence, it is difficult to determine the fault parameters uniquely only from the levelling data. Considering the aftershock distribution obtained in the present analysis, the one-fault model given by TAKEO et al. (1983) seems too simple to describe the actual fracture mechanism of the Urakawa-Oki earthquake.

We wish to express our sincere thanks to Mr. Morihiro Tanizaki, Captain of Hokushin Maru No. 18, and Professor Shoichi Yamamoto, Captain of Training Ship Hokusei Maru, Hokkaido University, for offering us opportunities to work on board. We also thank the officers and crews of the Hokusei Maru for their skilled ship maneuvering and help. We are also indebted to Mr. Yoshinobu Motoya of the Research Center for Earthquake Prediction, Hokkaido University, for his cooperation in the deployment of OBS's.

We are grateful to Dr. Sadaomi Suzuki and staffs of the Research Center for Earthquake Prediction for kindly allowing us to use the arrival time data at the permanent land stations of RCEP. Our thanks are also due to Messrs Hiroki Miyamachi and Susumu Kato of Department of Geophysics, Faculty of Science, Hokkaido University, for revising and compiling the arrival time data at the land stations.

We also express our thanks to Dr. Mitsuhiro Matsu'ura of the Geophysical Institute, Faculty of Science, the University of Tokyo, for critically reading the manuscript. 
The computations were made on HITAC M200H at the Computer Center, Hokkaido University.

This work was supported by a special grant from the Ministry of Education Science and Culture of Japan.

\section{REFERENCES}

Asada, T., T. Yamada, and H. Shimamura, Pop-up ocean bottom seismograph, Progr. Abstr. Seismol. Soc. Japan, 1979(2), 114 (in Japanese).

Asano, S., N. Den, H. HotTa, T. Yoshil, Y. IChinose, N. SaKaJiri, and T. Sasatani, Seismic refraction and reflection measurements around Hokkaido. Part 2. Crustal structure of the continental slope off Hidaka, J. Phys. Earth, 27, 497-510, 1979.

FujI, S. and T. MORIYA, Upper crustal structure in Hidaka district by refraction measurements using the quarry blasts, Geophys. Bull., Hokkaido Univ., 42, 169-190, 1983.

Hirata, N., T. Yamada, H. Shimamura, H. Inatani, and K. Suyehiro, Spatial distribution of microearthquakes beneath the Japan trench from ocean bottom seismographic observation, Geophys. J. R. Astron. Soc., 73, 653-669, 1983.

ICHIKAWA, M. and E. MochIzUKI, Travel time table for local earthquakes in and near Japan, Pap. Meteorol. Geophys., 22, 229-290, 1971.

MAtsu'ura, M. and N. Hirata, Application of generalized inversion technique of local earthquakes I. Mathematical formulation and computer program, Progr. Abstr. Seismol. Soc. Japan, 1981(1), 44 (in Japanese).

Matsu'ura, M. and N. Hirata, Generalized least-squares solutions to quasi-linear inverse problems with a priori information, J. Phys. Earth, 30, 451-468, 1982.

Matsu'ura, M., T. Yamada, K. Shibuya, H. Inatani, T. Tanimoto, N. Hirata, and J. Ito, Aftershock observation of the 1978 Miyagi-Oki earthquake by ocean bottom seismographs II, Progr. Abstr. Seismol. Soc. Japan, 1978(2). 4 (in Japanese).

MiYaMACHI, H. and T. MoriYA, Velocity structure beneath Hidaka Mountains in Hokkaido, Japan, 1983 (submitted to J. Phys. Earth).

Moriya, T., H. MiYamachi, and S. Kato, Spatial distribution and mechanism solutions for foreshocks, mainshock, and aftershocks of the Urakawa-Oki earthquake of March 21, 1982, Geophys. Bull., Hokkaido Univ., 42, 191-214, 1983a (in Japanese with English abstract).

Moriya, T., H. MiYAMAchi, S. Kato, and H. OKaDA, Spatial distribution of aftershocks of the earthquake off Urakawa, Hokkaido, March 21, 1982, General Report on the Urakawa-Oki, Japan, Earthquake, of March 21, 1982, pp. 29-37, 1983b (in Japanese with English abstract).

МоточA, Y., Seismic activity with relation to the 1982 earthquake off Urakawa, Hokkaido, General Report on the Urakawa-Oki, Japan, Earthquake, of March 21, 1982, pp. 13-20, 1983 (in Japanese with English abstract).

Shimamura, H., T. Iwasaki, K. Suyehiro, T. Yamada, N. Hirata, and T. Urabe, Aftershock observation of Off Urakawa earthquake of 1982 by using ocean bottom seismographs, General Report on the Urakawa-Oki, Japan, Earthquake, of March 21, 1982, pp. 51-55, 1983 (in Japanese with English abstract).

SuzukI, S. and Y. Motoya, Time variation of the seismic activity before and after the 1982 earthquake off Urakawa, Hokkaido, General Report on the Urakawa-Oki, Japan, Earthquake, of March 21, 1982, pp. 57-69, 1983 (in Japanese with English abstract).

TAKANAMI, T., Three-dimensional seismic structure of the crust and upper mantle beneath the orogenic belts in southern Hokkaido, Japan, J. Phys. Earth, 30, 87-104, 1982.

TAKEO, M., M. KASAHARA, and K. ABE, Focal process of the Urakawa-Oki earthquake of March 21, 1982, General Report on the Urakawa-Oki, Japan, Earthquake, of March 21, 1982, pp. 1-12, 1983 (in Japanese with English abstract).

Utsu, T., Catalog of large earthquakes in the region of Japan from 1885 through 1980, Bull. 
Earthq. Res. Inst., Univ. Tokyo, 48, 401-463, 1982 (in Japanese with English abstract).

YAMADA, T., Spatial distribution of microearthquakes and crustal structure revealed by ocean bottom seismographic observation, Ph. D. Thesis, the University of Tokyo, 1980.

Yamada, T., T. Asada, and H. Shimamura, A pop-up ocean bottom seismograph, Progr. Abstr. Seismol. Soc. Japan, 1981(2), 126 (in Japanese).

Yamada, T., H. Shimamura, and T. Asada, Low noise pop-up ocean bottom seismographs, 1983 (in preparation).

Yamada, T., H. Inatani, M. Matsu'ura, K. Shibuya, T. Tanimoto, N. Hrrata, T. Asada, E. MurakAMI, and A. TAKAGI, Aftershock observation of the 1978 Miyagi-Oki earthquake by ocean bottom seismographs. I, Progr. Abstr. Seismol. Soc. Japan, 1978(2), 31 (in Japanese). 